\title{
EMIPLOYMENT RESTRICTIONS AND THE PRACTICE OF LAW BY ALIENS IN THE UNITED STATES AND ABROAD
}

\author{
VOLKER KNOPPKE-WETZEL*
}

\section{OUTLINE}

I. History of Legislative aNd JUdicial EMPLOYMENT Restrictions UPON ALIENS IN THE UNITEd States
A. Climate at the Turn of the Century
B. Climate Around World War I
C. Climate Around World War II
D. Trends in Recent Years

II. Aliens' Exclusion from the Practice of Law in the Untede States:

A Case Study of Discrimtnation

A. Historical Setting

B. Recent Judicial Developments Regarding Practice of Law by Aliens

(1) State Supreme Court Rulings

(2) Landmark United States Supreme Court Ruling

C. Recent State Bar Admission Practices

(1) Policies

(2) Practices of Administrative Discretion Without Due Process

III. In re Griffiths: ASSESSMENT OF THE LANDMARK

A. Doctrinal Importance

(1) Facts and Holding of the Case

(2) The Majority's "Suspect Classification-Strict Scrutiny" Analysis

(3) The Dissenters" "Officer of the Court" Analysis. Integration or Denigration?

B. Future Practice of Law by Aliens in the United States

C. Future Practice of Law by Americans Abroad

IV. SUMMARY AND CoNCLUSIONS

\section{History of Legislative AND Judicial EMployment RESTRICTIONS UPON ALIENS IN THE UNITED STATES}

\section{A. Climate at the Turn of the Century}

At early American common law, citizen/subjects of a nation at peace with the United States were presumed to be unhostile and were afforded all the constitutional rights granted to United States citizens. During the nineteenth century, twenty-two states and territories al-

* Visiting Professor of Law, Center for Interdisciplinary Research (ZIF), The University of Bielefeld, Germany, 1974-75; Assistant Professor of Extension Law, University of Wisconsin-Madison; B.A. 1966, Wayne State University; M.A. 1967, Goethe University, Frankfurt, Germany; M.A. 1969, J.D. 1971, University of Wisconsin-Madison. 
lowed such aliens the right to vote. However, laws were eventually passed in every state disenfranchising aliens. ${ }^{1}$

During the last two decades of the nineteenth century two major developments occurred which stimulated the growth of institutionalized discrimination against aliens in the forn of state legislation severely restricting aliens' employment opportumities. ${ }^{2}$ One was the marked change of the United States fronı an agrarian nation to a heavily industrialized and urban society. The other contemporaneous development was a substantive change in the composition of the immigrants' national origins, the immigrants of Western European origin declining froin ninety percent of the total immigration in the period 1820-74 to only 17.7 percent in 1907.3

In order to counter the dramatic shift in the predominant nationalities of Anerican immigrants, Congress passed legislation designed to close this country's doors to moral and physical undesirables ${ }^{4}$ and to bar certain nationalities altogether, particularly the Chinese. ${ }^{5}$ However, this legislation did not make the immigrants who were already in America any more familiar with American customs or the English language nor did it affect the total number of entering immigrants, which continued to increase each year to more than a million in $1905 .^{\circ}$ Most immigrants were forced to reside in the cities and work in factories because they lacked famiharity with the custorns and language of their new homeland and because farm land had becone scarce by that time. Immigrant arrivals reduced the economic opportunities of all American citizens and threatened the protectionist policies of industrial unionism. ${ }^{7}$

As a response to the continued influx of immigrants into their cities, the individual states enacted restrictive legislation which either directly excluded noncitizens from work opportumities, or at least put

1. See M. Konvitz, The Alien and the Asiatic in American Law 180 (1964). HEREAFTER THE FOLLOWING CITATION WILL BE USED IN THIS ARTICLE:

Note, Constitutionality of Restrictions on Aliens' Right to Work, 57 Colum. L. Rev. 1012 (1957) [hereinafter cited as Constitutionality of Restrictions].

2. See The Chinese Exclusion Case, 130 U.S. 581, $594-97$ (1899). See generally Constitutionality of Restrictions.

3. See S. Kansas, U.S. Immigration Exclusion and Deportation and CitizenSHIP OF THE UNITED STATES OF AMERICA 265-66 (3d ed. 1948).

4. Act of August 3, 1882, ch. 376, 22 Stat. 214.

5. Act of May 6, 1882, ch. 126, 22 Stat. 58.

6. See S. KANSAS, supra note 3.

7. See W. Van Vleck, The administrative Control of aliens 6 (1932); Scully, Is the Door Open Again?-A Survey of Our New Immigration Law, 13 U.C.L.A.L. REv. 227, 232 (1966). 
them at a substantial disadvantage in comparison to citizens of the United States. The states generally justified these employment restrictions as a valid exercise of police power in regulating occupations considered to be associated with criminal activities or thought to be inherently vicious and harmful. Noncitizens as a class were presumed to be less familiar with United States laws and customs than were native born or naturalized citizens, and their participation in particular occupational activities was believed to present an imcreased danger to public welfare. ${ }^{8}$ The restrictions were also justified as a natural corollary to the proprietary theory, based on the common property doctrine: citizens were given priority over aliens, even immigrants who planned to become citizens, since the state as trustee controlled the property for its citizens, who were the owners. ${ }^{9}$ During this period of our history, states were usually successful in ineeting legal challenges to employment restrictions on the basis of the above justifications. The exceptional case of this period is the 1886 Supreme Court decision of Yick Wo v. Hopkins. ${ }^{10}$

The Court in Yick Wo declared that resident aliens were "persons" within the ineaning of the fourteenth aniendinent's equal protection clause. ${ }^{11}$ The case involved an ordinance which allowed a city commission, as a "safety" nieasure, to withhold laundry business licenses from those establishments located in wooden buildings. The Court recognized that in fact the law was established to ehminate the participation of the Chinese in the laundry business in San Francisco. ${ }^{12}$ The Court held the ordmance unconstitutional and stated that

no reason for it [discrimination] exists except lostility to the race and nationality to which the petitioners belong, and which in the eye of the law is not justified. . . . [P]ublic administration which enforces it is a denial of the equal protection of the laws and a violation of the 14th Amendment. ${ }^{13}$

The Fourteenth Amendinent . . . is not confined to the protection of citizens. . . . These provisions are universal in their application, to all persons within the territorial jurisdiction, without regard to any differences of race, or color, or of nationality. . . .14

Yick Wo v. Hopkins was the noncitizen employee's single promise of

8. See, e.g., Murphy v. California, 225 U.S. 623 (1912).

9. See, e.g., McCready v. Virginia, 94 U.S. 391, 395 (1877).

10. 118 U.S. 356 (1886).

11. Id. at 369 .

12. Id. at 374 .

13. $l d$.

14. Id. at 369 (emphasis added). 
this period, but it turned out to be illusory for many generations to come.

\section{B. Climate Around World War I}

The period running from the turn of the century to the beginning of World War I was characterized by a mood of national isolationism. Congressional legislation in 1917 expanded the grounds for qualitative exclusion, restricted the numerical quotas relating to Asian immigration, imposed an eight dollar head tax on every alien, and excluded a variety of alien types, for example, polygamists, anarchists, revolutionaries, alcoholics, and contract laborers. ${ }^{15}$ In 1924, Congress further restricted immigration by establishing the "national origins system," a system of quantitative and qualitative immigration controls which became the foundation for immigration legislation in 1952 and thereafter. ${ }^{16}$

The states continued to enact legislation restricting aliens' work opportumities, and throughout the nation state courts endorsed the systematic exclusion of aliens from various occupations. Exclusions sanctioned by the judiciary covered the following fields: retail liquor sales, ${ }^{17}$ lrawkers and peddlers, ${ }^{18}$ auctioneers, ${ }^{10}$ motorbus operators, ${ }^{20}$ pawnbrokers, ${ }^{21}$ soft drink sales, ${ }^{22}$ and pool rooni operators. ${ }^{23}$ Courts also endorsed exclusion of aliens from participation in public works projects $^{24}$ and denied them the right to fish, ${ }^{25}$ hunt, ${ }^{26}$ and own land. ${ }^{27}$ One court even endorsed a statute that forbade aliens to own dogs! ${ }^{28}$

Courts continued to justify employment discrimination agamst aliens on the ground that aliens as a class did not have the necessary qualifications of character to work in occupations which were poten-

15. Act of Feb. 5, 1917, ch. 29, §§ 2-3, 39 Stat. 875-78.

16. Immigration Act of 1924, ch. 190, $\S 2$ et seq., 43 Stat. 153, as amended, 8 U.S.C. $\S \S 1101$ et seq. (1970).

17. Trageser v. Gray, 73 Md. 250, 20 A. 905 (Ct. App. 1890).

18. Commonwealth v. Hana, 195 Mass. 262, 81 N.E. 149 (1907); State v. Montgomery, 94 Me. 192, 47 A. 165 (1900).

19. Wright v. May, 127 Minn. 150, 149 N.W. 9 (1914).

20. Gizzarelli v. Presbrey, 44 R.I. 333, 117 A. 359 (1922).

21. Asakura v. Seattle, 265 U.S. 332 (1924).

22. Miller v. City of Niagara Falls, 207 App. Div. 798, 202 N.Y.S. 549 (1924).

23. Clarke v. Deckebach, 274 U.S. 392 (1927).

24. Heim v. McCall, 239 U.S. 175 (1915); Crane v. New York, 239 U.S. 195 (1915).

25. McCready v. Virginia, 94 U.S. 391 (1877).

26. Patsone v. Pennsylvania, 232 U.S. 138 (1914).

27. Terrance v. Thompson, 263 U.S. 197 (1923).

28. Commonwealth v. Preoziki, 28 Pa. Dist. 352 (1918). 
tially associated with criminal activity or with activities representing a potential danger to public welfare, ${ }^{29}$ and on the ground that a state should give priority to citizens over aliens. ${ }^{30}$ Eventually, some courts even suggested that aliens as a class are incapable of advanced learning. ${ }^{31}$

The Supreme Court in 1915 again vindicated aliens' rights, contrary to the prevailing judicial climate. In Truax v. Raich ${ }^{32}$ the Court abruptly, though briefly, changed its direction by analyzing alien discrimination in employment through "equal protection," "unreasonable classification," and "federal supremacy" language.

In Truax v. Raich, the Court considered the constitutionality of an Arizona law that forced busmesses with more than five employees to hire American citizens for at least eighty percent of their work force. In striking the statute as violative of equal protection, the Court stated that the police power of the state to make reasonable classifications to promote health, safety, morals, or welfare "does not go so far as to make it possible for the State to deny lawful inhabitants, because of their race or nationality, the ordinary means of earning a livelihood."33 The Court emphasized that though the parties were engaged in private employinent, the right to work was "of the very essence of . . . personal freedom and opportunity . . .."34 However, the Court did not rest solely upon its equal protection argument. Rather, it also gave considerable weight to a federal supremacy argument, namely that denial of all work opportunities would be tantamount to denying aliens "entrance and abode," a state action which would contravene the supremacy clause because sucli power over immigration was exclusively within the province of the federal government. ${ }^{35}$

Truax $v$. Raich represented a realizable gain for a number of aliens and thus was less of an illusion than was Yick Wo v. Hopkins before the turn of the century. Although legislative interference with all occupations was struck down, the Court did not extend the Truax rationale to the situation where only a single occupation was prohibited to aliens ${ }^{36}$ because the Court was unable to find the same arbitrariness.

29. See Murphy v. California, 225 U.S. 623 (1912).

30. See McCready v. Virginia, 94 U.S. 391, 395 (1877).

31. Sashihara v. State Bd. of Pharmacy, 7 Cal. App. 563, 565, 46 P.2d 804, 806 (1935).

32. 239 U.S. 33 (1915).

33. Id. at 41.

34. Id.

35. Id. at 42.

36. Clarke v. Deckebach, 274 U.S. 392 (1927). 
Furthermore, commentators have not interpreted Truax as extending to professions. ${ }^{37}$ Thus, while Truax made substantial de jure and de facto inroads into the obstacles faced by aliens, the decision still did not fully open employment opportunities for many qualified and aspiring aliens.

\section{Climate Around World War II}

In the period between World War I and World War II, congressional limitations on immigration persisted. Race exclusions continued to flourish and, on a case-by-case basis, the following groups were included under this exclusion category: Japanese, Chinese, Hindus, Afghans, Burmese, Hawaiians, Koreans, and Filipinos. ${ }^{38}$ Although the resignation of the United States Commissioner of Immigration and Naturalization in 1944 was largely motivated by his opposition to this racial immigration policy, ${ }^{39}$ this era of discrimination did not end until Congress passed the 1952 act which terminated the United States policy of denying to aliens, upon the basis of race, the right to become a citizen through naturalization. ${ }^{40}$

The courts of this period also continued to support legislation excluding aliens froin certain occupations, as long as the statute did not exclude aliens from all employment opportunities. ${ }^{41}$

During the late 1930's and early 1940's, most Americans were too concerned with pressing economic problems, domestic welfare legislation, and real or imaginary national security problenis related to World War II to worry about immigration policy or employment probleins of aliens. It is therefore all the more surprising that during this period some members of the Supreme Court started to show a serious concern for aliens as a class. For example, Justice Stone may well have laid the foundation for improved treatment of aliens in United States v. Carolene Products Co. $^{42}$ By way of dictum, he noted that a stricter standard of judicial review may be necessary when statutes are directed at particular national or other minority groups and that a more searching judicial inquiry would be necessary in these cases because these groups are imsular, politically helpless victims of possible unconstitutional restrictions of their liberties. ${ }^{43}$ This suggestion for a stricter standard

37. See, e.g., Fellman, The Alien's Right to Work, 22 Minn. L. Rev. 137 (1938).

38. M. Konvirz, supra note 1 , at 96.

39. Id. at 80.

40. Immigration and Nationality Act, 8 U.S.C. $\$ 1422$ (1970).

41. See text accompanying notes 32-37 supra.

42. 304 U.S. 144 (1938).

43. Id. at 152 n.4. Mr. Justice Stone's suggestion for a stricter standard arose in the context of a discussion of the presumption of constitutionality in the construction 
probably contributed to the expansive interpretation of the equal protection clause as it relates to aliens, which was articulated in the 1946 decision of Takahashi v. Fish and Game Commission. ${ }^{44}$

Takahashi declared unconstitutional a California statute denying aliens commercial fishing privileges equal to those of citizens by prohibiting all noncitizens, even resident aliens, from fishing within the three-mile offshore limit. Using the supremacy clause rationale that had justified Truax, the Court noted that "the power of a state to apply its law exclusively to its alien inhabitants as a class is confined within narrow limits," ${ }^{45}$ and held that laws which create "burdens on the entrance or residence of aliens lawfully within the United States [are in] conflict with [the] constitutionally derived federal power to regulate immigration . . .."46 Citing Yick Wo, which held the equal protection clause to apply to aliens as well as citizens, the Court concluded that all persons lawfully in the country "shall abide 'in any State' on an equality of legal privileges with all citizens under nondiscriminatory laws . . . . . ",47 and held that the "special interests" asserted by California were inadequate. ${ }^{48}$

Takahashi was another important milestone in the einployment discrimination history regarding aliens, but like its predecessors the decision seemed to stop short of providing aliens with the same protections as citizens. The Court relied heavily on the suprenacy clause ${ }^{48}$ to justify a more stringent equal protection standard and closer judicial scrutiny regarding classifications involving aliens. Instead, the Court could have justified its decision entirely on the basis of equal protection, a rationale which might have led the Court to apply the tern1 "suspect classification" to aliens-the same term that the Court later used in the racial discrimination cases to necessitate the showing of a "compelling state interest." Bo Because the word "suspect" was absent in Takahashi and because the Court relied heavily on the supremacy clause, many writers and courts interpreted the decision as suggesting an internediate

of federal legislation: "There may be narrower scope for operation of the presumption of constitutionality when legislation appears on its face to be within a specific prohibition of the Constitution, such as those of the first ten amendments, which are deemed equally specific when held to be embraced within the Fourteenth." Id.

44. 334 U.S. 410 (1948).

45. Id. at 420 .

46. Id. at 419.

47. Id. at 421 .

48. Id. at 422 .

49. Id. at 419; see U.S. CoNST. art. VI, cl. 2.

50. See, e.g., Loving v. Virginia, 388 U.S. 1, 11 (1967). See generally Developments in the Law-Equal Protection, 82 HARv. L. REv. 1065, 1088 (1969). 
category for review of alienage classifications, that is, a lesser standard than that used in the racial discrimination cases. ${ }^{\text {1 }}$ The "suspect classification" test was not fully developed until the $1960{ }^{\circ}$ s, $^{52}$ so the absence of the word "suspect" in Takahashi, a 1948 decision, might not have indicated the Court's intention to apply a lesser standard for alienage classification. However, courts and scholars have rejected such an interpretation as well as the possible alternative interpretation that the supremacy clause might inerely have been the judicial vehicle for formulating a "suspect classification" test. ${ }^{.53}$

Although Takahashi represented another step forward in opening einployment opportunities to aliens in the United States, its promise was not completely fulfilled. Many state legislatures and courts interpreted the language of Takahashi as a license to continue the practice of limiting rights of aliens with regard to numerous employment opportunities and other benefits.

\section{Trends in Recent Years}

After World War II and until the 1960's, legislatures and courts generally continued to relegate aliens to an inferior status in spite of Takahashi. This is illustrated by the plethora of state, and some federal, statutes which continued to restrict, often with judicial approval, the aliens' ability to earn a living. For example, legislatures continued to exclude aliens from the following occupations: certified public accountant, architect, dentist, professional engineer, physical therapist, optonietrist, pharmacist, real estate broker, and veterinarian. ${ }^{54}$ State legislatures and courts continued to justify such occupational restrictions on the ground that these occupations involved dangerous, antisocial, or health-related activities which aliens could not be trusted to perform as well as citizens. ${ }^{55}$ Other legislation restricted alien land own-

51. See, e.g., Constitutionality of Restrictions 1027-28; Note, Protection of Alien Rights Under the Fourteenth Amendment, 1971 Duke L.J. 583, 597-99; Note, California's Prohibition Against Contractors Employing Aliens in Public Works Declared Unconstitutional, 11 HARv. INT'x L.J. 228, 238-39 (1970); Note, National Power to Control State Discrimination Against Foreign Goods and Persons: A Study in Federalism, 12 STAN. L. REV. 355, 365-67 (1960).

52. See, e.g., Loving v. Virginia, 388 U.S. 1, 11 (1967); McLaughlin v. Florida, 379 U.S. 184, 198 (1964).

53. See note 159 infra.

54. See, e.g., N.J. STAT. ANN. \$ 45:2A-8 (Supp. 1974) (certified public accountant); id. § 45:3-5 (architect); id. \$ 45:6-3 (1963) (dentist); id. § 45:8-35 (professional engineer); id. \$ 45:9-37.3 (Supp. 1974) (physical therapist); id. § 45:125 (optometrist); id. $\S 45: 14-7$ (pharmacist); id. $\$ 45: 15-9$ (real estate broker); id. $\S 45: 16-7$ (veterinarian).

55. See Constitutionality of Restrictions 1021-27. 
ership, employment in public works projects, eligibility for civil service positions, and eligibility to receive public assistance and welfare benefits. ${ }^{56}$ This legislation was often justified on the basis that job competition with citizens should not be increased and that aliens should not receive any public funds. ${ }^{57}$

Since the 1960's, lowever, a series of cases has establislied the foundation for the alien's entry into all occupations and has set the stage for the abolishment of other restrictive legislation. In 1969, the California Supreme Court led the way, as it has so often done in constitutional matters, in Purday \& Fitzpatrick v. State. ${ }^{58}$ Relying heavily on Takahashi, the California court overturned a statute that prohibited the employment of aliens in public works projects. Rejecting earlier interpretations, ${ }^{59}$ it read Takahashi to mean that alienage was a suspect classification and that the proprietary or special imterest theory no longer had vitality. ${ }^{60}$ The court ruled out the state-police-power theory by reasoning that the right-privilege distinction was without merit and concluded that the interest of favoring American citizens over aliens was not a compelling state interest, although it might well be a legitimate one. ${ }^{61}$

Two years later, the United States Supreme Court followed suit in Graham v. Richardson ${ }^{62}$ by finding unconstitutional an Arizona statute which demied welfare benefits to resident aliens who had not resided in Arizona for at least fifteen years. ${ }^{63}$ The Court held that an alien is a "person" for equal protection purposes and that citizens can have no "special public interest" in tax revenues to which aliens liave also contributed on an equal basis. ${ }^{64}$ The mere saving of welfare costs, the Court said, cannot justify an otherwise invidious classification. ${ }^{65}$

One essential factor made Graham a pivotal decision: for the first time, the Court placed aliens squarely and without limitation in the

56. See Sullivan, Alien Land Laws, A Re-Evaluation, 36 TeMP. L.Q. 15 (1962); Constitutionality of Restrictions; Note, State Discrimination Against Mexican Aliens, 38 Geo. Wash. L. Rev. 1091 (1970); Comment, Equal Protection and Supremacy Clause Limitations on State Legislation Restricting Aliens, 1970 UTAH L. REv. 136.

57. Cf. Constitutionality of Restrictions 1016-19.

58. 71 Cal. 2d 566, 456 P.2d 645, 79 Cal. Rptr. 77 (1969).

59. See note 159 infra.

60. 71 Cal. $2 d$ at 584-85, 456 P.2d at $657-58,79$ Cal. Rptr. at $89-90$ (1969).

61. Id. at $581 \& 585,456$ P.2d at $655 \& 658,79$ Cal. Rptr. at $87 \& 90$.

62. 403 U.S. 365 (1971).

63. In the same decision, the Court also held that a Pennsylvania statute which denied welfare benefits to noncitizens was unconstitutional. Id. at 368-70.

64. Id. at 375-76.

65. Id. at 375, quoting Shapiro v. Thompson, 394 U.S. 618, 633 (1969). 
"strict judicial scrutiny" category based on a suspect classification ${ }^{60}$ and applied the "compelling state interest" test to restrictions placed upon their rights. ${ }^{.7}$ The stringent Court-developed "compelling state interest" test ${ }^{68}$ requires the state to show affirmatively that the classification is necessary because of a compelling state interest. The test has been applied in areas where classifications either affected fundamental rights $^{69}$ or were inherently suspect. ${ }^{70}$ Statutes that include suspect classifications are subject to rigid judicial scrutiny, ${ }^{71}$ and the burden of proof is on the state to justify them ${ }^{72}$ by affirmatively establishing a compelling state interest. ${ }^{73}$

The precedential importance of Graham was enhanced because the Court did not avoid the suspect classification issue. Instead of applying the compelling state interest test in the context of a classification which only infringed upon a fundamental right, such as the right to travcl, ${ }^{74}$ the Court applied the test because it considered alien classifications inherently suspect. Therefore, Graham's importance goes beyond the doctrinal breakthrough of applying the more stringent compelling state interest test to the area of alien rights. By avoiding possible alternative holdings, the decision strongly indicated the arrival of a judicial climate which would give unprecedented protection to the rights of resident aliens. The combination of this climate and the broad equal protection analysis of Graham provided lower courts with the tools for imvakidating legislation restricting aliens in many areas other than welfare, such as public education, ${ }^{75}$ real estate, ${ }^{76}$ and employment. ${ }^{77}$

66. By 1971 the Supreme Court had declared the following classifications suspect: race (Loving v. Virginia, 388 U.S. 1, 9 (1967)), nationality (Korematsu v. United States, 323 U.S. 214, 216 (1944)), and political allegiance (Williams v. Rhodes, 393 U.S. 23 (1968)). Perhaps wealth is also a suspect classification (Harper v. Virginia Bd. of Elections, 383 U.S. 663 (1966)).

67. 403 U.S. at 372.

68. Historically, the Court has applied two tests to determine if a classification violates the equal protection clause. See Developments in the Law, supra note 50 . The more traditional "rational relation test" invalidated classifications only if they had no rational basis and were purely arbitrary. See Dandridge v. Williams, 397 U.S. 471 (1970). Thus, statutory validity required only a reasonable relationship between the classification used and any legitimate end that the legislature could achieve.

69. See, e.g., Shapiro v. Thompson, 394 U.S. 618, 638 (1970).

70. See, e.g., Loving v. Virginia, 388 U.S. 1 (1967).

71. See Korematsu v. United States, 323 U.S. 214, 216 (1944).

72. See Loving v. Virginia, 388 U.S. 1, 9 (1967).

73. See Korematsu v. United States, 323 U.S. 214, 216 (1944).

74. See Shapiro v. Thompson, 394 U.S. 618 (1969).

75. See Hosier v. Evans, 314 F. Supp. 316 (D.V.I. 1970).

76. See Oyama v. California, 332 U.S. 633 (1948).

77. See Teitscheid v. Leopold, 342 F. Supp. 299 (D. Vt. 1971); Dougall v. Sugar- 
Two years later, the Supreme Court, in Sugarman v. Dougall, ${ }^{78}$ affirmed one of these post-Graham decisions in the employment discrimination area. The case involved a number of resident aliens who were discharged froin their jobs because of a New York law which inade noncitizens ineligible for permanent positions in New York's competitive class of state civil service. Relying mainly on Graham's holding that classifications based on alienage are subject to close judicial scrutiny because aliens as a class are clearly a discrete and insular minority, ${ }^{70}$ and on the Court's interpretation of Takahashi-namely, that the state's power "to apply its laws exclusively to alien inhabitants as a class is confined within narrow limits"80 - the Court held that a state's flat prohibition against employment of aliens is constitutionally invalid on fourteenth amendment equal protection grounds.

The Court employed the "strict judicial scrutiny" test by analyzing the substantiality of the state's interest in enforcing the statute, the means of enforcement, and the "narrowness of the limits within which the discrimination was confined." 81 In its analysis the Court recognized that the state had a legitimate interest "in establishing its own form of government, and in limiting participation in that government to those who are within the basic conception of a political community," $" 82$ and that the state had broad power in defining this political cominunity. However, the Court rejected the state's practice because the citizenship restriction which the state employed to reach these legitimate objectives swept too indiscriminately and could "not withstand close judicial scrutiny."\$3 The Court held that, in order to ineet the test, the state's means must be precisely drawn in their application and narrowly confined in light of the acknowledged purpose..$^{84}$

In a lengthy epilogue, the Court emphasized that it was only condemning a flat employment ban and that it would still be possible for an alien to be refused state employment on the basis of an individualized determination, even if that basis was noncitizenship, if the re-

man, 330 F. Supp. 265 (S.D.N.Y. 1971), affd, 413 U.S. 634 (1973); Raffaelli v. Committee of Bar Examiners, 7 Cal. 3d 288, 496 P.2d 1264, 101 Cal. Rptr. 896 (1972); Hsieh v. Civil Serv. Comm'n, 79 Wash. 2d 529, 488 P.2d 515 (1971). But see Jalil v. Hampton, 460 F.2d 923 (D.C. Cir.1972).

78. 413 U.S. 634 (1973). The case is discussed further, together with In re Griffiths, in text accompanying notes 159-73 infra.

79. Id. at 642, citing Graham v. Richardson, 403 U.S. at 372.

80. 413 U.S. at 642 , citing Takahashi v. Fish \& Game Comm'n, 334 U.S. at 420.

81. 413 U.S. at 642.

82. Id. at 642-43, citing Dunn v. Blumstein, 405 U.S. 330, 334 (1972).

83. 413 U.S. at 643.

84. Id. 
striction "rests on legitimate state interests [(e.g., 'preservation of the basic conception of a political community')] that relate to qualifications for a particular position [(e.g., that of an important state elective or nonelective officer who participates directly in the formulation, execution or review of broad public policy)]." ${ }^{\text {s5 }}$

Despite Graham's and Sugarman's progressive suspect-classification analysis regarding discriminatory alienage legislation and the creation of a positive climate of cliange for the better, aliens are not yet universally treated like United States citizens in the realm of employinent. For example, direct or indirect restrictions through professional licensing requirements continue to exist in nost states, and the Federal Civil Service Commission discriminates against all resident aliens as a class by prohibiting thein froin qualifying for approxmately $2,689,800$ government jobs. ${ }^{86}$ Recent federal public works appropriations legislation also continues to retain restrictive language. ${ }^{87}$ These restrictions are difficult to attack judicially because the federal government can hardly be accused of interference with a preempted federal right and because the equal protection clause of the fourteenth amendment by its own terms applies only to the states. Although a strong judicial tradition has accorded aliens the protection of the fifth amendment due process clause (which is applicable to federal action), ${ }^{88}$ possible limitations on the usefulness of the fifth amendment in this area ${ }^{80}$ and a strong judicial tradition of according the executive branch broad latitude in the regulation of civil agency positions serve as potential impediments to the invalidation of discriminatory federal civil service regulations. ${ }^{90}$

85. Id. at 647 .

86. U.S. Civil Serv. Comm'n Federal Civilian Manpower Statistics, Monthly Release No. SM 137110 (Oct. 1971).

87. See, e.g., Public Works Appropriations Act of 1970, Pub. L. No. 91-144, § 503, 83 Stat. 366-67.

88. See, e.g., Galvan v. Press, 347 U.S. 522, 530 (1954) (alien is a "person" under due process clause); Wong Wing v. United States, 163 U.S. 228, 238 (1896) (fifth, sixth, and fourteenth amendments apply to aliens).

89. See generally Bolling v. Sharpe, 347 U.S. 497 (1954). But see Bailey v. Richardson, 182 F.2d 46, 57 (D.C. Cir. 1950), aff'd, 341 U.S. 918 (1951).

90. See Jalil v. Hampton, 460 F.2d 923 (D.C. Cir. 1972); Note, Aliens and the Civil Service: A Closed Door?, 61 Geo. L.J. 207 (1972). But see Hampton v. Mow Sun Wong, 333 F. Supp. 527 (N.D. Cal. 1971), discussed in note 234 infra. Discriminatory federal legislation might, however, be successfully attacked on the basis of various executive orders, e.g., that the policy of the government is to "provide equal opportunity in Federal employment for all persons, to prohibit discrimmation in employment because of race, color, religion, sex or national origin . . . Ex Exec. Order No. 11,478, 3 C.F.R. 134 (1969 Coinp.), 42 U.S.C. $\& 2000$ e (1970). However, the term "national origin" can be interpreted as being consistent with a citizenship requirement. 


\section{Aliens' Exclusion from the Practice of LaW in the United States: A Case Study of Discrimination}

\section{A. Historical Setting}

Just as many states have prevented aliens from pursuing occupations involving the sale of alcoholic beverages ${ }^{91}$ or the managennent of pool halls ${ }^{92}$ and have excluded aliens from entering such diverse professions as optometry, psychology, architecture, medicine, and teaching: ${ }^{93}$ the vast majority of states have also prevented noncitizens from practicing law..$^{94}$ Historically, this exclusion has been justified by the police power of the state to regulate the interest of the public's health, safety, or welfare, i.e., the protection of the public from "imcompetent" and "dishonest" practitioners. ${ }^{95}$ To this end, the states set whatever standards the judiciary and/or legislature deein to be necessary to assure competency in the practice of law. Such standards usually have excluded the noncitizen, even though he might otherwise have made a competent attorney.

Immigrants have been refused entry into the bar and have been excluded from bar examination sessions even if they entered law school immediately after arrival in the United States with an intent to acquire United States citizenship as soon as possible and finished law school within three years, thereby fulfilling all regular state competency requirements for the practice of law. Such well-intentioned citizens-tobe generally have had to wait two years after graduation from law school before becoming eligible for admission to the bar because federal legislation in most cases requires five years of full-time residency in the United States before citizenship eligibility is reached. ${ }^{96}$ The noncitizen had no chance of being permitted to practice as long as he remained "merely" an immigrant. Even long-time residence in the United States, payment of taxes, and service im the Armed Forces has had no bearing on an alien's eligibility for admission to the bar. As far as bar associations, legislatures, state boards of bar examiners, and

91. See, e.g., Tragereser v. Gray, 73 Md. 250, 20 A. 905 (Ct. App. 1890).

92. See, e.g., Clarke v. Deckebach, 274 U.S. 392 (1927).

93. See note 54 supra.

94. M. Konvitz, supra note 1 , at 188. See also 5 MARTINDALE-HUbBell LAW DIRECTORY (103d ed. 1971). See also discussion in text accompanying note 132 ff infra.

95. See Constitutionality of Restrictions 1021-27.

96. The Immigration and Nationality Act, 8 U.S.C. $\$ 1427$ (a) (1970) provides, inter alia:

No person ... shall be naturalized unless such petitioner, (1) ... has tesided coutinuously, after being lawfully admitted for permanent residence, within the United States for at least five years . . . . 
the judiciary have been concerned, to be a lawyer meant first to become a United States citizen.

Aliens have seemed to experience a harder time penetrating the bars surrounding the legal profession than even those of the other professions from which they were excluded. The following are some of the reasons that have been advanced in favor of excluding aliens from bar admission: a lawyer in the United States must appreciate the spirit of American institutions, take the necessary oath to support the Constitution, and remain accessible to his clients; the practice of law is a privilege, not a right; the lawyer is an officer of the court; and it is difficult to train civil law attorneys in the common law. These justifications for exclusion of alien attorneys withstood legal attacks again and again. ${ }^{07}$

In 1957, the Umited States Supreme Court indirectly came to the aid of the alien applicant by developing a test for the validity of bar admission conipetency standards in Schware v. Board of Bar Examiners. ${ }^{98}$ This test became a major tool for aliens attacking discriminatory bar admission rules even though Schware itself did not concern an alien petitioner. ${ }^{99}$ The Court lield that

[a] State cannot exclude a person from the practice of law or from any other occupation in a manner or for reasons that contravene the Due Process or Equal Protection Clause of the Fourteenth Amendment. . . . A State can require high standards of qualification, such as good moral character or proficiency in its law, before it admits an applicant to the bar, but any qualification must have a rational connection with the applicant's fitness or capacity to practice law. ${ }^{100}$

Although the Schware test encouraged an increased number of challenges, legal attacks by aliens continued to fail during the next fifteen years. A 1964 survey shows that the situation in most states had not inaterially changed. ${ }^{101}$ The few states which did not require citizenship for bar admission did so because state statutory language either ignored the inatter or permitted practice of law by aliens who had filed citizenship intentions with the federal court ("first papers"). Tennes-

97. However, these justifications were eventually rejected. See notes 106-10 infra and accompanying text.

98. 353 U.S. 232 (1957).

99. Schware dealt, inter alia, with the question of whether a former member of the communist party per se fails to meet standards of good moral character. Ill, at 243 . 47.

100. Id. at 238-39.

101. See Ohira \& Stevens, Alien Lawyers in the United States and Japan-A Comparative Stuly, 39 WASH. L. Rev. 412 (1964). See also Application of Skousen, 79 Ariz. 325, 289 P.2d 406 (1955). But cf. Petition of Rocafort, 186 So. 2d 496 (Fla. 1966). 
see and Virginia had no specific requirements, but nevertheless had developed a historical pattern of prohibiting alien attorneys from practicing law. Georgia, Massachusetts, Montana, Oklahoma and Oregon allowed bar admission to resident aliens who had declared their intention to become citizens as soon as they were eligible under federal law. Only Illinois changed its discriminatory exclusion provisions when a concerted effort on the part of some niembers of the bar persuaded the Illinois Suprenie Court to amend its Court Rules by eliminating the citizenship requirement in $1967 .^{102}$

The turning point for alien lawyers finally came in 1971-72. At about the same time the United States Supreme Court in Graham $v$. Richardson ${ }^{103}$ created a judicial climate favorable to the granting of full constitutional rights to resident aliens, four published state supreme court decisions reconsidered bar admission rules excluding aliens. Three of the decisions favored the admission of qualified alien residents, ${ }^{104}$ and one upheld the discriminatory rules, only to be reversed by the United States Supreme Court in a decision even broader in scope than the three favorable state supreme court decisions. ${ }^{105}$

\section{B. Recent Judicial Developments Regarding Practice of Law by Aliens}

\section{(1) State Supreme Court Rulings}

In Application of Park, ${ }^{106}$ the Alaska Supreme Court made a thorough analysis of the major policy arguments favoring exclusion of aliens from the practice of law and rejected them all. Policy arguments had usually developed along the following lines: The purpose of bar admission rules and licensing requirements is to insure that lawyers are fit to practice law; aliens are unfit because, by inference, they lack the kind of competence, integrity, and morality which distinguishes the citizen lawyer; they do not have the requisite appreciation of American institutions; ${ }^{107}$ and they cannot take the oath to support the United

102. ILL. S. CT. R. 701, 36 IIl. 2d 183 (1967). The Rule was amended again in 1971. IlL. S. CT. R. 701. See Fisher \& Nathanson, Citizenship Requirements in Professional and Occupational Licensing in Illinois, 45 ChICAGo B. RECORD 391 (1964).

103. 403 U.S. 365 (1971).

104. Application of Park, 484 P.2d 690 (Alas. 1971); Raffaelli v. Committee of Bar Examiners, 7 Cal. 3d 288, 496 P.2d 1264, 101 Cal. Rptr. 896 (1972); In re Chi-Dooh $\mathrm{Li}, 79$ Wash. 2d 561, 488 P.2d 259 (1971).

105. In re Griffiths, 162 Conn. 249, 294 A.2d 281 (1972), rev'd, 413 U.S. 717 (1973).

106. 484 P.2d 690 (Alas. 1971).

107. See, e.g., Large v. State Bar, 218 Cal. 334, 23 P.2d 288 (1933); Matter of O'Neill, 90 N.Y. 584 (1882). 
States Constitution because they may still owe their allegiance to another country, ${ }^{108}$ and therefore cannot take the oath as an officer of the court. ${ }^{108}$ An additional reason frequently given for exclusion of aliens from the legal profession was that the possibility of war between the Umited States and the alien's country might necessitate the seizure of the alien with resultant injury to his client. ${ }^{110}$ For these major reasons, and because the practice of law was seen as a privilege burdened with conditions rather than as a right, ${ }^{111}$ exclusion of aliens from the practice of law was viewed as proper, patriotic, and right in light of the general goal of assuring that only the fit practice law.

The Alaska court reasoned, however, that the state could find a fairer way to test the applicant's competence, integrity, and morality other than by the traditional, mechanical assumption that noncitizens are lacking in these characteristics. The court pointed to the fact that certain requirements, such as the requirements that the applicant be a graduate of an approved law school, be of good moral character, have followed a prescribed course of study, and have passed the bar examination, already tested these qualities. Furthermore, the court noted that the states are free to develop new and better ways to test all bar admission applicants' competence, integrity, and morality.

The court held that the argument that alien applicants do not appreciate American institutions was vague at best, and one's understanding of the American system and the role of law in that system "may be determined much better by tests than by looking at the applicant's nationality."112 Furthermore, the court felt that after preparing for a profession dedicated to operating within American democratic institutions, it was probable that the alien law student had learned to appreciate the spirit of American institutions as muclı as the native or naturalized citizen of the United States.

The Alaska court rejected as an unsupported hypothesis the argument that the alien lawyer cannot support the United States Constitution by oath. ${ }^{113}$ Indeed, an alien is subject to conscription into the armed forces, and, when serving, lie must take an oath to his "true faith

108. See, e.g., Large v. State Bar of Cal., 218 Cal. 334, 23 P.2d 288 (1933).

109. See, e.g., In re Admission to the Bar, 61 Neb. 58, 59, 84 N.W. 611,612 (1900).

110. See, e.g., Ex parte Thompson, 10 N.C. 196 (1824).

111. See generally M. KonviTZ, supra note 1, passim.

112. 484 P.2d at 693. See also Keenan v. Board of Law Examiners, 317 F. Supp. 1350 (E.D.N.C. 1970), where a court announced that "[n]either legal competence nor ethical fitness depends upon cultural provincialism .... . Too often even lifelong residents of a community have no knowledge of even the basic rudiunents of the governmental units closest at hand." Id. at 1359.

113. 484 P.2d at 693. 
and allegiance" and to "support and defend the Constitution of the United States against all enemies, foreign and domestic."114 By requiring the oath, Congress has unade intent and ability to support the Constitution the essential factors rather than the possession of a certificate of naturalization. Once an applicant shows lawful residence and a sincere intent to become a citizen, the court concluded, there is "no reason why an applicant . . . who meets all other qualifications . . . may not honestly and without regard to the laws of his place of origin take an oath to support the Constitution of the Umited States."115

The argument that an alien lawyer cannot be an officer of the court was rejected by the Alaska court as another way of saying that the attorney must take the oath to support the Constitution. The court concluded that there is nothing in the phrase "officer of the court" which should exclude aliens who are educated, well-versed in the laws of the United States and the particular state, competent, lonest, and ready to take an oath of support or loyalty and to serve both client and court. ${ }^{116}$ The remote possibility that during time of war the alien might be seized by the government was dismissed as a basis for excluding aliens for the reason that the practical effect of this occurrence would be no different froin the death or incapacity of a citizen attorney, so far as the clients are concerned. ${ }^{117}$

The Alaska court primarily based its decision to abolish its bar admission citizenship requirenent on the complete absence of sound policy reasons to retain it. Furthermore, the court abohished the requirenient even though it was a statutory one and suggested in a footnote that a strong constitutional equal protection argunient could be made, but decided it was unnecessary to reach this question. ${ }^{118}$ Nevertheless, the court limited admission to those alien applicants who in federal

114. This language is found in both 10 U.S.C. $\$ 502$ (1970) (oath for all enlistees); and 5 U.S.C. $\$ 3331$ (1970) (oath for all officers). For a general discussion of the draft laws' impact on aliens, see Roh \& Upham, The Status of Aliens Under United States Draft Laws, 14 HARv. INI'L L.J. 501 (1972).

115. 484 P.2d at 694. See also Law Students Research Council, Inc. v. Wadmond, 401 U.S. 154, 178 (1971), where the nature of the oath was seen by the majority and dissent as merely promissory, the declarant promising that he will perform certain duties in the future.

116. 484 P.2d at 695 .

117. Id. at 694. See also ABA CODE of Professional ResponsibILITY, Disciplinary Rule 2-110 (1969), which sets guidelines dictating the procedure by which an attorney should withdraw from employment.

118. 484 P.2d at 695 n.27. The argument suggested by the Alaska court was founded upon the traditional rational relation test:

Since the classification of citizenship bears no reasonable relationship to the purpose of insuring that lawyers in Alaska are fit to practice law, the requirement arguably offends equal protection. Id. 
court had sworn a declaration of intent to become a United States citizen. ${ }^{119}$ The effect of this ruling was that only resident aliens (immigrants) who intended to becoine United States citizens would be eligible for admission to the Alaska bar.

In In re Chi-Dooh $\mathrm{Li}^{120}$ the Washington Supreme Court followed the lead set by Park. The court amended its rule excluding aliens on policy grounds alone by smiply citing Park for "some of the salutory reasons for this rule change."121 The Washington state decision likewise avoided a holding on equal protection or other constitutional grounds and also limited admission only to those permanent resident aliens who had filed a declaration of intent to become citizens.

Raffaelli v. Committee of Bar Examiners ${ }^{122}$ was the third state court decision favorable to alien attorneys withm a twelve-month period. The Califorma Supreme Court reconsidered an attack on exclusion of aliens from the bar for the first time since it had rendered a negative decision in a case involving a similar attack thirty-nine years earlier. ${ }^{123}$ Raffaelli, unlike Park in Alaska and Chi-Dooh Li in Washington, which restricted themselves to policy arguments alone, for the first time unequivocally struck down an exclusion provision on constitutional grounds as offending the equal protection clause of the United States Constitution and of the California Constitution. ${ }^{24}$ The thoughtful and comprehensive opimion relied heavily on Graham v. Richardson and generously cited Purday \& Fitzpatrick $v$. State by stating that "any classification which treats all aliens as undeserving and all United States citizens as deserving rests upon a very questionable basis." ${ }^{125}$ In overruling a thirty-nine-year-old California decision which dealt with the same issue, the court noted that

[i]n the light of modern decisions safeguarding the rights of those among us who are not citizens of the United States, the exclusion appears constitutionally indefensible. It is a lingering vestige of a xenophobic attitude . . . which also once restricted nembership in our bar to persons who were both "inale" and "white." It should now be allowed to jom the anachronistic classifications among the crumbled pedestals of history. ${ }^{126}$

119. Id. at 696-97.

120. 79 Wash. $2 d 561,488$ P.2d 259 (1971).

121. Id. at 562 n.1, 488 P.2d at 260 n.1.

122. 7 Cal. 3d 288, 496 P.2d 1264, 101 Cal. Rptr. 896 (1972).

123. The 1933 case discussing this question was Large v. State Bar, 218 Cal. 334, 23 P.2d 288 (1933).

124. See 7 Cal. 3d at 305, 496 P.2d at 1275, 101 Cal. Rptr. at 907.

125. Id. at 299, $496 \mathrm{P} .2 \mathrm{~d}$ at $1271,101 \mathrm{Cal}$. Rptr. at 903.

126. Id. at $292,496 \mathrm{P} .2 \mathrm{~d}$ at $1266,101 \mathrm{Cal}$. Rptr. at 898. 
The court weighed the state's interests under the compelling state interest rules ${ }^{127}$ and concluded that the challenged classification did not have a "rational connection with the applicant's fitness or capacity to practice law."128

\section{(2) Landmark United States Supreme Court Ruling}

The Connecticut Supreme Court became, in In re Griffiths, ${ }^{129}$ the second state court, together with the California Supreme Court, to consider the validity of an equal protection attack upon the exclusion of aliens from the bar. However, unlike the California court, the Connecticut court rejected the constitutional challenge and supported its decision mainly with the argument that a Connecticut attorney, as an officer of the court, has powers, over and above those afforded to attorneys in other states, which place him in such an integral role in the judicial system as to require citizenship. ${ }^{130}$ The holding of the Connecticut Supreme Court was soon reversed by the United States Supreme Court. ${ }^{131}$

Compared to the Alaska, Washington, and California supreme courts, the United States Supreme Court was faced with a broader, and arguably distinguishable, question in Griffiths in that the alien applicant made it clear that she had no desire to become a United States citizen. By ruling in favor of the applicant, the Court not only granted to resident aliens (immigrants) the right to practice law, if otherwise qualified, but also may have extended the right to all aliens with work permits who neet regular and constitntionally valid noncitizenship-related state admission requirements. Thus, resident aliens are finally on equal footing with United States citizens in terms of the right to engage in the practice of law in any of the fifty states and, by inplication, to work in any of the professions for which they qualify. In light of the many decades of legislative discrimination against aliens and a multitude of court decisions ruling against alien rights, In re Griffiths is

127. Id. at 295-302, $496 \mathrm{P} .2 \mathrm{~d}$ at 1268-73, $101 \mathrm{Cal}$. Rptr. at 900-05.

128. Id. at 302, 496 P.2d at 1273, 101 Cal. Rptr. at 905, citing Schware v. Board of Bar Examiners, 353 U.S. 232, 239 (1957).

129. 162 Conn. 249, 294 A.2d 281 (1972), rev'd, 413 U.S. 717 (1973).

130. Id. at 255-56, 294 A.2d at 284; the State Supreme Court decisions of Alaska, Washington, California, and Connecticut have been discussed in the following literature: Note, Admission to the Bar and Legally Resident Aliens, 17 How. L.J. 682 (1972); Note, Aliens and the Practice of Law: Raffaelli v. Committee of Bar Examiners, 6 Loyola of L.A.L. REv. 398 (1973); Note, Equal Protection-Citizenship Requirement for Practice of Law Held Unconstitutional-Raffaelli v. Committee of Bar Examiners, 4 SeToN Hall L. Rev. 210 (1972); Comment, Aliens: The Unconstitutional Classification for Admission to the Bar, 4 ST. MARY's L.J. 181 (1972); Comment, Aliens and the Practice of Law, 12 WASHBURN L.J. 175 (1973).

131. In re Griffiths, 413 U.S. 717 (1973). 
a landmark decision. Furthermore, this decision has importance in the historical context of a progressive relaxation of discrimination against aliens by displaying the Court's equal protection analysis in the "suspect-clissification and strict scrutiny" category at a time when the Court seems to be changing its traditional analytical scheme in this area. And finally, the case, particularly Justices Burger's and Rehnquist's dissenting opinions, raises iniportant questions regarding the probability, extent, and form of iniplementation of the majority's holding by the various state institutions governing bar admission requirenents and practices in the states. These additional characteristics of In re Griffiths are discussed more extensively later in this Article.

\section{Recent State Bar Admission Practices}

\section{(1) Policies}

After the supreme courts of Alaska, Washington, and Califorma had decided to permit resident aliens to practice law in their respective states, the author conducted a survey in order to determine the actual bar admission practices in each state and to gauge the relative degree of influence of the three favorable state decisions on regulations and practices of bar admission in other states. ${ }^{132}$

The survey showed that as of December 1972 the publislied bar admission requirements fell into two general categories: (1) Thirty-eight states and the District of Columbia liad published bar adinission requirements which completely excluded noncitizens from the practice of law regardless of the applicant's good intentions of becoining a citizen as soon as possible. ${ }^{133}$ However, six of the thirty-eight

132. In most cases, information was obtained from the supreme courts of the respective states because, in the majority of jurisdictions, the judiciary makes the ultimate determination of admission standards and admissibility of individual applicants, see, e.g., Application of Houston, 378 P.2d 644, 645 (Alas. 1963); the courts view this power as an inherent one because bar admission is a judicial and not a ministerial function, see, e.g., Herberger v. Clark, 148 Conn. 177, 189-91, 169 A.2d 652, 658 (1961). A1though courts may alter rules for admission without the consent of the legislature or bar associations or administrative agencies such as bar conmissions, see, e.g., In re ChiDooh Li, 79 Wash. 2d 561, 488 P.2d 259 (1971), a few state supreme courts formally look to bar commissions or other agencies for guidance or delegate to them the development and administration of bar adınission requirements. In these few cases information for this survey was not received directly from the respective state supreme courts.

133. Arizona, Arkansas, Connecticut, Colorado, Delaware, Florida, Hawaii, Indiana, Iowa, Kansas, Kentucky, Louisiana, Maine, Maryland, Massachusetts, Michigan, Minnesota, Mississippi, Montana, Nebraska, Nevada, New Hampshire, New Jersey, New Mexico, New York, North Carolina, North Dakota, Ohio, Pennsylvania, Rhode Island, South Carolina, South Dakota, Tennessee, Vermont, Virginia, West Virginia, Wisconsin, Wyoming, and the District of Columbia. This information was obtained directly from the state supreme courts or state bar admission administrators during the fall of 1972. 
either permitted, or allowed the respective state supreme court to grant permission to, the applicant to take the bar examination as a resident alien. ${ }^{134}$ However, actual admission to the bar in those instances was delayed until the applicant had become a United States citizen. (2) Twelve states (including Alaska, Washington, and California which had changed their rules by court decision) had published rules that permitted aliens to practice law if they had resident alien (immigrant) status and had filed a declaration of intent with the federal court in their district shownig a good faith intention of becoming a United States citizen as soon as eligible under federal law. ${ }^{135}$ The noost liberal rule possible, namely, giving permission to practice law to any foreigner who otherwise qualifies, or to a resident alien who does not intend to beconie a citizen, was not the rule in any jurisdiction. However, in practice, some states required only a minimal showing of intent by the resident alien.

The survey furtlier disclosed that the two general categories of publisled legislative, judicial, or administrative rules did not always represent the true picture of state bar admission requirements. By neans of unpublicized rulemaking at least four additional states allowed resident aliens who could slow a good faith intent to become citizens to be admitted to state law practice. The suprenie courts of Iowa, Pennsylvamia, West Virginia, and Wisconsin, actimg as agencies administering bar admission requirements in their respective states, had developed, on an informal case-by-case basis, a rule to that effect. The most interesting feature of this administrative rulemaking system developed by the judiciary was the fact that the high courts did not disclose these changes in their published bar admission requirements. The potential alien attorney desiring to practice law in these states could not readily learn of these relaxed requirements. Official legislative, judicial, or administrative pronouncement failed to indicate that the courts had developed a different, more liberal, rule by means of ad loc exceptions.

\section{(2) Practices of Administrative Discretion Without Due Process}

In their function as bar admission regulators, the state supreme courts of Iowa, Pennsylvania, West Virgmia, Wisconsm, and perliaps

134. Florida, Maryland, Massachusetts, New Jersey, New Mexico, and North Dakota. Information was obtained directly from the state supreme courts or agencies administering bar admissions.

135. Alabama, Alaska, California, Georgia, Idaho, Illinois, Missouri, Oklahoma, Oregon, Texas, Utah, and Washington (and possibly the District of Columbia by court decision, see note 144 infra and accompanying text). Information was obtained directly from the state supreme courts or agencies administering bar admissions. 
other courts apparently have viewed their function as being similar to that of an administrative agency which grants, renews, denies, revokes, or suspends business or professional licenses. These courts have acted like administrative agencies when they have made decisions on a caseby-case basis and have developed rules designed to cover a multitude of potentially complex situations. Professor Kenneth Culp Davis has characterized this procedure of administrative rulemaking as "one of the greatest imventions of modern government."136 However, administrative rulenraking, in the Davis sense, is part of a nrachinery for structuring agency discretionary power, a part of a larger system which includes open plans, open policy statements, open rules, open findings, open reasons, and open precedents. ${ }^{137}$ The undisclosed decisions by the supreme courts have lacked this openness and perhaps have been subject to greater arbitrariness.

In exercising discretion as administrative agencies regulating state bar admissions, the four state supreme courts have paid little attention to Davis-like checks on administrative discretionary decision and rulemaking. When granting exceptions to the published admission rules for individual alien applicants, the courts have not published their decisions, nor have they developed criteria for review of individual determinations or published new admission rules. What might have prompted sucl1 secrecy? Did the high court justices reject the concept of openness im this instance because of their concern about adverse reactions from the general public or state bar organizations and their members to the possibility of noncitizens practicing law in their respective states? Did they fear that publicizing the liberalized admission rules would subject their particular states to a flood of alien attorneys? Or did they feel that aliens as a class did not represent interests powerful enough to require the provision of time-consuming, and possibly embarrassing, procedures and safeguards? The answers to these questions are subject only to speculation. What seems certain, however, is that the state supreme courts liave operated within a system of rule- and decision-making whicls allowed virtually unchecked discretion, short of a full-fledged appeal in the federal court system, in deciding to approve or reject a particular alien applicant. Also the courts' passive approval of a gen-

136. K. Davis, Administrattve Law Treatise $§ 6.15$, at 283 (Supp. 1970).

137. See generally K. DAvis, Discretionary Justice: A Preliminary Inquiry (1969). Three main chapters of this book are entitled "Confining Discretion," "Structuring Discretion," and "Checking Discretion." See also Davis, Open Findings, Open Reasons and Open Precedents in American Administrative Decisions, in Lroal THouaHT in the United States of AMERICA Under Contemporary Pressures 604 (J. Hazurd \& W. Wagner eds. 1970). 
eral policy of nondisclosure made it difficult for potential alien applicants even to find out about the real possibility of practicing law. These state supreme courts, when actimg as administrative bodies, have neglected to apply concepts of administrative law ${ }^{138}$ that would insure due process in their own operations.

There is no doubt that the state supreme courts, as courts and as admimistrative bodies supervising state bar admissions, should be governed in their conduct by admimistrative law concepts of due process. Proceedings involving the grant of licenses or permits have become legion. ${ }^{130}$ Although it is true that aliens, even those physically within the United States, can expect somewhat less in the way of due process treatment at the hands of administrative officials than a citizen, a resident alien is granted the same due process rights in these situations as the citizen. ${ }^{140}$ Relaxation of certain due process requirements for aliens seems to be justifiable only when loyalty-security questions are involved. ${ }^{141}$ The courts have given citizens and others the least due process rights in this area, and loyalty questions have caused due proc-

138. As the areas governed by administrative determinations have increased, so have the efforts of the courts to extend the concept of administrative due process-equal, even-handed, impartial justice under the law: "fundamental fairness," to use the second Justice Harlan's phrase. See, e.g., Duncan v. Louisiana, 391 U.S. 145, 181 (1968) (Harlan, J., dissentimg). Courts have increasingly protected the individual against discretionary administrative powers which were exercised unfairly, arbitrarily, discriminatorily, or through favoritism. The principle that administrative officials, agencies, and courts should not be above suspicion has been applied with special fervor where an individual's livelihood, profession, or liberty was at stake. Courts have held that in those instances, due process will require charges, the right to counsel, a hearing, confrontation with one's accuser, the examination and cross-examination of witnesses, and a reasoned determination. See, e.g., Morrissey v. Brewer, 408 U.S. 471 (1972) (parole revocation); Goldberg v. Kelly, 397 U.S. 254 (1970) (public assistance). In Justice Frankfurter's words, "[d]ue process is, perhaps, the least frozen concept of American law-the least confined to history and the most absorptive of powerful social standards of a progressive society." Griffin v. Illinois, 351 U.S. 12, 20-21 (1956) (concurring opinion).

139. See, e.g., Bell v. Burson, 402 U.S. 535 (1971) (a state motor vehicle license cannot be revoked without that procedural due process required by the fourteenth amendment); In re Ruffalo, 390 U.S. 544 (1968) (due process requires fair notice as to the reach of bar suspension procedure and the precise nature of the charges); Willner $v$. Committee on Character \& Fitness, 373 U.S. 96 (1963) (procedural due process requires confrontation and cross-exammation at a bar committee hearing which considers an applicant's fitness for admission to the bar); Hornsby v. Allen, 326 F.2d 605 (5th Cir. 1964) (due process im an administrative proceeding revolving around the grant of a retail liquor store license required confornity to the fair practices of Anglo-Saxon jurisprudence, notably adequate notice and a fair hearing); there have bcen inany other licensing cases in a variety of areas.

140. See Tieri v. Immigration \& Naturalization Serv., 457 F.2d 391 (2d Cir. 1972).

141. See, e.g., Law Students Civil Rights Research Council, Inc. v. Wadmond, 401 U.S. 154 (1971). 
ess problems for naturalized citizens as well as resident aliens. ${ }^{\mathbf{1 4 2}}$ However, loyalty of the applicant was not a threshold issue when the courts chose not to make the bar admission rule changes public knowledge and when they retained broad unchecked discretion to rule on an alien's apphication on a case-by-case basis in the absence of open decision-making guidelines.

If the courts feared a flood of applications by "undesirable aliens" in the future, this fear was unfounded. Data from the author's study show that such an imagined consequence would have amounted to a trickle at the most. Between 1967 and 1972 a total of only ten alien lawyers were admitted in the twelve states which openly admitted resident aliens into their bars under publicized liberal admission rules. During that period of time, the highest number of alien applicants in any one of these states ainounted to a total of three in Utah. By comparison, a total of five resident alien attorneys were admitted from 1971 to 1973 in the four states whose supreme courts had decided not to disclose the changed policy.

However, these figures do not convey the whole story. The four states' administrative policy of nondisclosure and its underlying reasons even affected some potential applicants who learned of the rule changes despite the secrecy surrounding them. At least two resident alien applicants, for example, were discouraged by the Clerk of the Wisconsin Supreme Court from even applying. Despite the fact that the court had overtly revised its bar admission policy a year earlier towards admitting, on a case-by-case basis, resident aliens who demonstrated a good faitli intent to become Umited States citizens, the clerk told thein that they were not eligible as noncitizens. The two law students who were about to graduate had to contact members of the high court personally in order to be assured that they could apply and would be admitted. ${ }^{143}$ The experienced agent of the court, the clerk, had interpreted the court's policy as one of general discouragement of alien applicants. The Wisconsin Supreme Court itself, when pressed by an alien applicant who had gamed knowledge of the past admission of an alien, revealed that it was using its informal case-by-case waiver rule as if it were granting an applicant a privilege, rather than a right, to be extended by a generous court only after careful consideration of informal information concerning the applicant in his absence. This experience was not unique to Wisconsin; applicants elsewhere ran into the same sort of problems. For example, an alien petitioner in Washing-

142. See, e.g., Brown v. United States, 356 U.S. 148 (1958).

143. This information was obtained from the two applicants themselves, who had sought the advice of the author. 
ton, D.C., was personally granted a waiver of the alien exclusion portion of the bar admission rule, but the court would not, at that time, commit itself to applying the same policy to other resident aliens similarly situated. 144

\section{In re Griffiths: AsSESSMENT OF THE LANDMARK}

\section{A. Doctrinal Importance}

\section{(1) Facts and Holding of the Case}

The Griffiths appeal was pursued by Mrs. Fre Le Poole Griffiths, a resident alien (immigrant) who came to the United States from the Netherlands in 1965 and became a resident of Connecticut by marriage to a Umited States citizen in 1967. By 1970, she was eligible to apply for United States citizenship, but she decided against applying at that time. That same year she graduated from Yale Law School and subsequently was denied permission to take the Connecticut bar examination solely because of a citizenship requirement imposed by a state supreme court rule..$^{145}$

In the Connecticut Suprene Court, she asserted that the regulation was unconstitutional, but her claim was rejected. ${ }^{146}$ The state of Connecticut had excluded aliens from the practice of law since 1879.147 The Connecticut Bar Examining Committee, in its brief to the Connecticut Supreme Court, defended this exclusionary admission rule, first, on the ground that a Connecticut lawyer's role as an "officer of the court" is a special one in that a Connecticut statute nuakes every lawyer a "Commissioner of the Superior Court," a power over and above that afforded to attorneys in other states. The Committee asserted that this function represents such an integral part of the judicial system as to require citizenship. The special powers granted in Connecticut are "to sign writs and subpoenas, take recognizances and administer oaths."148 Secondly, the Committee asserted that noncitizens would experience possible conflict of loyalties, vis-à-vis a citizen's undivided allegiance to the United States. The Committee concluded from this assertion that noncitizen lawyers might ignore their responsibilities

144. See Grover v. Committee on Admissions and Grievances of the U.S. Dist. Court for the Dist. of Columbia, Civil No. 110-71 (D.D.C. 1971). See also Note, Admission to the Bar, supra note 130 , at 690 n.48.

145. In re Griffiths, 162 Conn. 249, 294 A.2d 281 (1972), rev'd, 413 U.S. 717 (1973).

146. Id. at $268,294 \mathrm{~A} .2 \mathrm{~d}$ at 289 .

147. Id. at $253,294 \mathrm{~A} .2 \mathrm{~d}$ at 283.

148. Conn. Gen. Stat. ANN. $§ \S 51-85$ (1960). 
to the courts, or even to their clients, in favor of the interests of a foreign power and that consequently they could seriously damage public confidence in the profession and in the judicial system.

The Connecticut Supreine Court agreed with the Committee's reasoning and concluded that although attorneys are not officers of the state in the ordinary sense, their "unique status" as evidenced by "the extensive power . . . entrusted to them in the administration of justice, as well as the relationship of their functions to the administration of the constitutionally established judicial branch of the state government," clearly established a "rational connection" between a requirement of loyalty to the state and membership in the profession. ${ }^{140}$

The United States Supreme Court, with two justices dissenting, reversed the Connecticut Supreme Court. Citing Yick Wo v. Hopkins, Truax v. Raich, Takahashi.v. Fish and Game Commission, United States v. Carolene Products Co., and Graham v. Richardson, the Court leeld that this case presented a "suspect classification," which, to be constitutional, required the state to prove that "its purpose or interest is both constitutionally permissible and substantial [or compelling, or overriding, or important], and that its use of the classification is 'necessary ... to the accomplishment' of its purpose or the safeguarding of its interest." 150 Applying this standard, the Court concluded that the Committee had failed to show that the special powers of the Connecticut attorney involve state matters of such unique responsibility as to entrust thein only to citizen attorneys; that the Connecticut practice of law in and of itself offers meaningful opportumities to adversely affect United States interests; or that there is any relevance of citizenship to a likelihood that a lawyer will fail to protect faithfully the interests of his clients. ${ }^{151}$

The possibility that some noncitizens may be unsuited to the practice of law, the Court added, is no justification for a wholesale ban. ${ }^{162}$ The Court acknowledged a state's substantial interest in apphicants' qualifications and its freedoin to test the fitness of an applicant to practice law by examining such qualifications as competence, good moral character, agreement with an "attorney's oath," and continuing fitness after admission. ${ }^{153}$ However, the Court concluded that the Committee sinply did not establish that the classification excluding all noncitizens

149. 162 Conn. at $259-60,294$ A.2d at 286 .

150. 413 U.S. at 721-22 (emphasis added; footnotes omitted).

151. Id. at 724 .

152. Id. at 725 .

153. Id. at 725-27. 
was necessary to promote or safeguard these legitimate interests in high professional standards. ${ }^{154}$

In its brief to the United States Supreme Court, the Committee presented a third argument. Going beyond the scope of the opinion of the Connecticut Supreme Court, the appellee argued that the lawyer is an "office holder" in the sense in which that term is used in some federal statutes and im the Umited States Constitution (e.g., the constitutional provision disqualifying aliens froin "holding office" as President). ${ }^{155}$ The Committee contended that constitutional and statutory provisions of this type reflect a recognition that participation in the governmental structure as voters and office holders is inescapably an aspect of citizenship. The Court also rejected this argument by disagreeing with the notion that an attorney is an "officer" within the ordinary meaning of that term. The Court reasoned that one is not an official of the government by virtue of being a lawyer and that one's license to practice does not place him "so close to the core of the political process as to make him a formulator of government pohicy."158 The Court also commended the state court decisions of Raffaelli ${ }^{\mathbf{1 5 7}}$ and Application of Park ${ }^{\mathbf{1 5 s}}$ in a footnote and thus concluded that the Connecticut rule violated the equal protection clause.

\section{(2) The Majority's "Suspect Classification- Strict Scrutiny" Analysis}

One aspect of Griffiths' doctrinal inportance, in conjunction with Sugarman, is that the Court continued to support Graham's analysis of alienage classification as "suspect," which triggers the apphication of the "necessary-to-the-accomplishment-of-a-'compelling'-governmental interest" test. Furthermore, the Court, by iniphication, rejected a socalled "intermediate standard of review"159 of regulations which dis-

154. Id. at 727.

155. Id. at 728.

156. Id. at 729 .

157. Id. Raffaelli is discussed in text accompanying notes 122-28 supra.

158. 413 U.S. at 729. Park is discussed in text accompanying notes 106-19 supra.

159. During the last decade the Court has invalidated certain classifications on "near suspect" grounds, that is, by some intermediate standard of review. See, e.g., Reed v. Reed, 404 U.S. 71 (1971) (sex); Levy v. Louisiana, 391 U.S. 68 (1968) (illegitimacy).

Professor Gunther discussed the emergence of this intermediate standard of review and suggested a model of analysis as a supplement to the strict scrutiny standard (which would continue to apply in "established" suspect classifications and fundamental interest areas). His "means-focused" model would require that legislative means must substantially further legislative ends which have a substantial basis in actuality. This rcquirement would replace the minimum rationality standard and would allow avoidance of the ultimate value judgments about the legitimacy and importance of legislative purposes 
criminate against aliens. Another aspect of Griffiths' doctrinal significance is that the decision extended the "suspect classification-strict scrutiny" analysis to a state's police power, in this case the power to keep aliens from being einployed in one of the professions traditionally regulated by all states-the practice of law.

Justice Rehnquist's dissent highlighted the importance of the Court's continued use of the "suspect classification-strict scrutiny" analysis of classifications based on alienage. ${ }^{160}$ The need for the unequivocal use of sucli a standard in Griffiths was well summarized in a recent statement by a commentator that "the Court [in Graham] tortured prior case law in order to squeeze aliens into the inherently suspect area ...."161 If the Court had been less direct in espousing "strict scrutiny" in Griffiths and Sugarman, those decisions would have been vulnerable to the possibility of narrow interpretation or even overruling.

By implication, when the Court affirmed the "suspect classification-strict scrutiny" analysis, it chose not to move toward an "intermediate standard of review" in this case even though some major functional rationales for an inherently suspect classification status were absent in the facts of Griffiths. Usually the Court has denoted a statutory classification of persons suspect because: affected groups are discrete insular minorities; members of such groups are stigmatized; and the characteristics of such meinbers are congemital and essentially immutable. ${ }^{162}$ If these standards are applied to aliens in light of the language in Griffiths, it readily appears that the Court conceded that aliens meet the first criterion because they are a group which is precluded from access to the political process ("discrete and imsular"). The Court must liave tentatively assumed that Connecticut did not in fact adequately consider the aliens' interests when passing its discriminatory bar admission rules. Therefore, the Court assumed a protective role in order to prevent abuse of the democratic process. ${ }^{163}$ In the role of protector, however, the Court has traditionally intervened only when a classification stigmatized the members of the politically discrete and

which a fundamental interest analysis entails. Gunther, The Supreme Court, 1971 Term -Foreword: In Search of Evolving Doctrine on a Changing Court: A Model for a Newer Equal Protection, 86 HARv. L. REv. 1 (1972). For a critical analysis of this model, see Comment, Equal Protection in Transition: An Analysis and a Proposal, 41 FORDHAM L. REv. 605 (1973).

160. 413 U.S. at 653-57.

161. 10 DUQUESNE I. REv. 280, 282 (1971).

162. See note 66 supra. See Note, A Question of Balance: Statutory Classifications Under the Equal Protection Clause, 26 Stan. L. Rev. 155 (1973).

163. See also Graham v. Richardson, 403 U.S. 365, 372 (1971). 
insular class in a special way in the eyes of society ${ }^{164}$ and when the defining characteristics of nembers (e.g., race, national origin, alienage) were such that it was impossible for nembers to escape this status. ${ }^{165}$

In terms of the third functional rationale for the "suspect classification-strict scrutiny" standard, it can be argued that the petitioner did not possess characteristics or a status which was congemital and essentially immutable. ${ }^{166}$ The alien petitioners in Sugarman apparently were under no disability that precluded them from applying for and being granted the status of naturalized citizens. They simply had taken no steps to apply for citizenship. ${ }^{167}$ The petitioner in Griffiths elected to remain a citizen of the Netherlands even though she was eligible for Umited States citizenship, and she declared that she had no intention of becoming a Umited States citizen. ${ }^{108}$ If she had been so inclined, Mrs. Griffiths could have easily taken steps to alter her status from an immigrant to a naturalized citizen. In her particular case it could be argued that the classification and the requirements to overcome the effects of the classification neither severely stigmatized nor penalized her while, on the other hand, the state's interests involved are perhaps sufficiently weighty. ${ }^{169}$ However, in spite of inviting factual considerations, the Court did not relax or create exceptions to the Graham "suspect classification-strict scrutiny" analysis regarding alienage. The effect can only be a strengthening of the precedential value of Graham's fullfledged "suspect" treatınent of alienage and of Graham's impact, at least in the alienage area, and perhaps also on classifications of "discrete and insular" groups with similar characteristics. ${ }^{\mathbf{1 7 0}}$

Finally, Griffiths is also doctrinally significant because of its extension of active review to state pohce power. Graham dealt the death

164. See, e.g., Brown v. Board of Educ., 347 U.S. 483, 494 (1954).

165. See, e.g., Weber v. Aetna Cas. \& Sur. Co., 406 U.S. 164, 175 (1972).

166. Alienage is not an immutable characteristic except, perhaps, in the sense that once an individual has been branded as a "foreigner" others inay continue to regard him in this hight even if he becomes a citizen. Also, alienage characteristics may merge with iminutable national origin claracteristics such as accent, height, complexion, hair color, and so forth.

167. 413 U.S. at 638. Some meinbers of the class had not been residents of the United States for five years and thus were not eligible to apply immediately for citizenship. As Justice Rehnquist pointed out, however, there was nothing to indicate that these members would not be eligible for citizenship upon satisfaction of the durational residency requireinent. Id. at 650 n.1.

168. Id. at 718 n.1.

169. Cf. Tancil v. Woolls, 379 U.S. 19 (1964) (upholding the use of racial classifications in the context of record keeping).

170. Graham v. Richardson, 403 U.S. 365 (1971); Note, Alien Welfare Rights, 5 INT'L L. AND POL. J. 393 (1972). 
blow to the proprietary public interest doctrine, ${ }^{171}$ but it did not explicitly include the states' police power under the active review. In light of the Court's analysis in Griffiths and Sugarman, the states will now have to do more than casually justify their discriminatory employment classifications of aliens. In all likelihood, the courts will be striking down state statutes that discriminate against aliens under GrahamSugarman-Griffiths' strict scrutiny test ${ }^{172}$ unless the statutes address themselves to occupational arenas which are primarily political. ${ }^{173}$

\section{(3) The Dissenters' "Officer of the Court" Analysis: Integration or Denigration?}

Chief Justice Burger, in his dissenting opinion in Griffiths, chided the Court for the casual way in which it had articulated "suspect classification" as a code phrase.174 He then proceeded to limit his analysis to the articulation of his own pet code phrase-cofficer of the court"as though it embraced a reasoned and constitutionally valid basis for excluding aliens froin the practice of law. Together with Justice Rehnquist, who shared his views, he accused the Court of contributing to the "denigration of the posture and role of a lawyer as an 'officer of the court" "175 by allowing noncitizens, a class of persons which the two dissenters presumed to be insufficiently integrated into American society, to practice law. ${ }^{176}$

171. See 403 U.S. at 374.

172. Typically, subjecting a statute to strict scrutiny has meant that the statute would be invalidated, and invoking the ininimum rationality test meant that the statute would be upheld. See Developments in the Law, supra note 50, at 1076-77 (1969). Various occupational restrictions have been nullified in Califoruia in light of Raffaelli, discussed in text accoinpanying notes 122-28 supra. See 55 Op. CAL. ATTY. GeN. 80 (1972). For examples of current state discriminatory classifications, see Comment, Constitutional Restrictions of Aliens, 40 TENN. L. REv. 235, 245-53 (1973).

173. Sugarman v. Dougall, 413 U.S. at 642-43, 647-49; In re Griffiths, 413 U.S. at 727-29.

174. 413 U.S. at 730. The Chief Justice expressed agreement with soine aspects of the policy reasons militating in favor of relaxing sone of the restraints on the practice of law by aliens because, in his opinion, we live in a "rapidly shrinking "one world" " and "a large number of American nationals are admitted to the practice of law in more than a dozen countries." Id. However, enlightened, good, and sound policy reasons did not persuade him within the context of the decision because he objected to the Court's constitutional analysis, i.e., its expansive reading of the fourteenth amendinent and the "rather casual way [in which, in recent years, the Court] has articulated the code phrase 'suspect classification' as though it embraced a reasoned constitutional concept." $1 d$. Instead of further discussing the heart of the Court's equal protection analysis, Chief Justice Burger left the articulation of a reasoned attack on the code phrase "suspect classification" to fellow dissenter Justice Rehnquist.

175. Id.

176. Id. at 731-33. 
Chief Justice Burger developed his dissenting argument by first constructing his own definition of the position of "officer of the court" -a concept which he traced back to the English system. Then he filled out his definition froin that which, in his opinion, separates the legal profession from other trades and vocations: the requirement of extraordinary obligations to duty and conscience derived from the attorney's peculiar imdependence from government and client. In his opimion, the requirement that the American lawyer be an officer of the court traditionally was to serve the purpose, and had the effect, of making the lawyer a professional man by keeping his role performance "strictly within and never in derogation of high ethical standards." 177

After articulating his definition of the officer of the court in this fashion, Chief Justice Burger observed that in some countries lawyers are traditionally agents of their governments. He found this relationship between government and lawyers "so alien to our imdependent bar that I find it difficult to see how nationals of such a country, inculcated with those ideals and at the same time unwilling to accept American citizenship, could be properly integrated into our system."178 Since he then assumed that such "proper integration," as defined by himself and Justice Rehnquist, is a prerequisite for fulfilling his definition of the role of "officer of the court," he came to the conclusion that it is reasonable and rational for the states to assume that some noncitizen lawyers, even if tramed in the United States and able to meet the fitness, competency, and oath requirements, are unable to fulfill the role of "officer of the court," and that this assumption is itself a reasonable and rational basis for exclusion of noncitizens by means of a per se rule. He concluded that he would "not stretch the Fourteenth Amendment to force the States to accept any national of any country siniply because of the recital of the required oath and passing of the bar examination." 179

Finally, he disagreed with the majority opinion so strongly that he recommended that the states avoid the full inipact of Griffiths by adopting, by statute or rule of court, a reciprocal proviso which would adınit to the practice of law only the alien applicants of such other countries as admit American citizens to practice. ${ }^{180}$

In a separate dissenting opinion applicable to both Sugarman and Griffiths, Justice Rehnquist rejected the "suspect classification" and "compelling state interest" analysis in favor of a "rational basis" test

177. Id. at 733.

178. Id.

179. Id.

180. For a discussion of possible reciprocal provisos, see text accompanying notes 254-58 infra. 
and would have required a complete "integration" of the applicant into the American social system and experience, proved either by American birth or by naturalization. ${ }^{181}$ While the majority opinion required citizenship for "political community" activities and positions, ${ }^{182}$ Justice Rehnquist would liave also permitted citizenship to be a requirement for "such extraordinary" occupational activities as the practice of law. ${ }^{183}$ $\mathrm{He}$ admitted that states could more accurately define and avoid the overbreadth inherent in a test such as "integration" by asking each applicant to demonstrate his or her familiarity with American history, tradition, principles, institutions, language, political and social mores and structures, and to indicate his or her willinguess to be integrated into

181. Sugarman v. Dougall, 413 U.S. at 649. Justice Rehnquist's dissent applied to both the Griffiths and Sugarman decisions, which were issued on the same day. It seems significant that Chief Justice Burger joined the majority in Sugarman, whereas in Griffiths he concurred with Justice Rehnquist's objections to the same Court's suspect classification analysis. However, Justice Rehnquist's objections were primarily directed towards the Sugarman majority's analysis (in which Chief Justice Burger joined). This seems to indicate that Chief Justice Burger's real concern in Griffiths is with the different target of the Griffiths Court's use of the "code phrase 'suspect classification," namely the lawyer.

182. See note 173 supra and accompanying text.

183. Justice Rehnquist first objected to what, in his opinion, was the Court's holding that aliens are not really different from citizens and to the Court's "inherently suspect" analysis of alienage classification. He argued first that the framers of the fourteenth amendment did not intend alienage to be "suspect" nor did they intend to protect "discrete and insular minorities." 413 U.S. at 649-50. The amendment's language lacked those phrases, and historical records show that framers only wanted to prohibit racial discrimination. Secondly, he felt that, unlike the case with racial minorities, aliens' "status" is not forever encumbered in that aliens can acquire citizenship. Id. at 650. Thirdly, he pointed out that the United States Constitution itself recognizes a basic difference between citizens and aliens in at least eleven instances and that the fourteenth amendment itself defines "alien" status as a lesser included class. Id. at 651-52. He concluded from this that a contiuuing status in and relationship to American society greater than mere "presence" or "residency" was contemplated by the framers. Fimally, be argued that neither Truax, Takahashi, United States v. Carolene Products Co., nor Graham, which relied on these cases, offers const.tutional au:hority that would suggest application of a "suspect classification" analysis in aliznage cases. He suggested that, at best, the precedents indicate that the Court has coine to disagree with past justifications supporting the rational basis test, but not that the test should be discarded on constitutional grounds. Id. at 653-54.

In his attempt to meet the rational basis test, Justice Rehnquist stated further that the alien-citizenship distinction is important beyond the political arena, and that the alien, to be treated like a citizen, must show that he is integrated into and committed to the American system as a whole. Id. at 660. He stated that this is why Congress, before granting citizenship, requires a showing of language skills, politienl, historical and social understanding, and good moral character. He concluded that it is rational and reasonable to require that lawyers, as officers of the court, must possess more than technical skills and that Connecticut, in light of congressional citizenship requirements, did not act irrationally in assuming that citizens have a greater understanding of American society and thus requiring citizenship for bar admissions. Id. at 663 . 
the American social system. But he argued that states need not do so because Congress provided a statutory presumption of "integration" for naturalized citizens based on durational and qualificational requirements for aliens who want to demonstrate both their willingness and ability to integrate into the American social systein as a whole, not just into the American "political community."

In other words, Chief Justice Burger and Justice Rehnquist urged that alien-citizenship classifications are proper not just in the "political community" context, but also in the extraordimary socio-economic sphere of the practice of law where requirements of duty and conscience are extraordinary due to the lawyer's role as "officer of the court." By urging a citizenship requirement, they in essence advocate "per se" durational (five years) and qualificational ("integration" and "loyalty") requirements. Their analysis is, to borrow Chief Justice Burger's words, really a casual articulation of code phrases as if they embraced reasoned constitutional concepts. Their opinions are even inore extraordinary (a) because the policy aspects of their analysis have been discussed at length and rejected by state supreme courts in Application of Park and Raffaelli v. Committee of Bar Examiners, ${ }^{184}$ cases which they did not mention; (b) because similarly justified durational and "local custonis" requirements by the state bar admission agencies have been ruled unconstitutional by a series of courts when these agencies applied them rather than applying uniform qualification tests related to capacity and fitness to practice law; ${ }^{185}$ and (c) because loyalty requirements in the bar admission context have been severely limited by the Court on constitutional grounds. ${ }^{186}$

The acceptance of Chief Justice Burger's and Justice Rehnquist's rationale would bar froin the practice of law resident aliens (immigrants) who might be thoroughly familiar with American customs and traditions (and would therefore be beyond the scope of the dissenter's rationale), and yet would permit citizens to practice law who inay not share this knowledge. For example, the dissenters placed no weight upon time spent in the United States by the resident alien applicant prior to obtaining a resident alien (immigration) visa. Many applicants have had experience in the United States as visitors or as high school, undergraduate, or graduate students on student or exchange student visas. On the one hand, one can easily imagine an alien applicant, say, a British national, who spent his or her senior year in an

184. See text accompanying notes 106-19, 122-28 supra.

185. See notes 217-21 infra and accompanying text.

186. See notes 207-16 infra and accompanying text. 
American high school, attended American undergraduate and law schools-a duration of at least eight years-and married his or her American high school or college sweetheart during these student years. Following graduation from law school this hypothetical alien decided to settle in the United States, and consequently obtained a resident alien visa. After spending eight of his or her nost formative years in the United States, the applicant, if the dissenters had their way, would have to wait at least another three years-a total of eleven years-for bar admission eligibility because of a presuniption that the resident alien applicant is less informed about American life than the average citizen. On the other hand, one can mragine a citizen-apphicant who was born and raised abroad, received his undergraduate education abroad, studied his first year of law there, and subsequently came to the United States, where he obtamed a law degree in two years (receiving one year credit for his studies abroad). The dissenters would permit this citizen-applicant, who has set foot in the United States only two years before, to practice law as a matter of right because, by their rationale, the applicant-citizen is presuned to be integrated into American society, more loyal, and more aware of historical and contemporary thoughts and trends in American life than the hypothetical resident alien who has resided in the United States for eleven or more years and who is nrarried to an American citizen. ${ }^{187}$

Beyond this obvious shortcoming, the blanket citizenship requirenient also nuakes no provision for those intelligent and strongly motivated resident aliens who might reach the dissenters' desired state of awareness in a shorter tine than the statutory durational citizenship requirenent. In the opimion of this author at least, it would be fairer to presume that aliens who graduate froin an American law school have greater intelligence and motivation than many citizens, and that they have had considerable contact with America through public instruction, private reading, and personal relationships with Americans. Yet, the dissenters imcluded thein in the same class with those who might have had little or no such contact. ${ }^{188}$

187. Compare In re Ashford, 4 Hawaii 614 (1883), where the petitioner was a graduate of an American law school and licensed to practice in two states, yet was denied admission to the Hawaiian bar because he was not a citizen. Petitioners in Application of Park and In re Chi-Dooh $\mathrm{Li}$ had resided and been educated in the United States for many years.

188. Cf. Faruki v. Rogers, 349 F. Snpp. 723 (D.D.C. 1972), where the court characterized this kind of classification as "unduly rough and imprecise," with a "patently overbroad sweep." Id. at 730-31.

In an effort to test Chief Justice Burger's and Justice Rehnquist's assumptions about the naturalization procedure and the citizenship test being a singularly all-important 
Another peculiar feature of Chief Justice Burger's dissent is the manner in whicl he used a reference to the British "officer of the court" tradition ${ }^{189}$ (upon which the American concept is based ${ }^{190}$ ), a comparative analogy which he has made in a variety of contexts in recent years because he seems to have a genuine affection for the British way of domg things. ${ }^{191}$ Chief Justice Burger's comparative analogy stopped short of mentioning that in England citizenship is not now required for the practice of law, ${ }^{192}$ and that it was never unanimously required in the United States. ${ }^{103}$ Further, he failed to explain how the English manage to keep their standards of ethics and conduct so high with alien practitioners in their midst. His urgings elsewhere that American lawyers must develop officer-of-the-court-like qualities in law school behies his urging in Griffiths that aliens cannot practice law in spite of graduation from an American law school. ${ }^{194}$ Considering that the Brit-

measure of an alien's integration, knowledge, and understanding, in late 1973 and early 1974 the author administered a sample "citizenship test" to two sets of ten new citizens one mouth after their naturalization ceremony. The test used was the Daughters of the American Revolution's sample test on American history, government, aud culture, which is issued to the applicants as a study tool before their citizenship examination. (Besides facility with English, the naturalization law requires a demonstration of knowledge of American history and government. Immigration and Nationality Act, 8 U.S.C. \$ 1423 (1970).) The author found that seventy-five perceut of the new citizens failed more than fifty per cent of the questions on the sample test. The nature of the questions is such that a noncitizen law graduate would undoubtedly know the answers to more questions. This was coufirmed by a small test taken by three noncitizeus-a Canadian, an Ethiopiau, and a German-who recently graduated from law school in Wisconsin. By comparison, ten citizeus picked at random on a Madison, Wisconsin sidewalk (mostly college students) all failed more than fifty per cent of the sample test questions.

189. In re Griffiths, 413 U.S. at 732.

190. The coinmon law of England disqualified the alien because law practice required an oath of allegiance and because the alien was the subject of another country. $1 \mathrm{~W}$. Blackstone, Commentaries oN THE LAw OF England *367 (1755). However, an exception was made for an alien who had signed letters patent to become a citizen. Id. at $* 375$.

191. On one occasion, Chief Justice Burger praised the English legal profession's "very high standards of ethics and conduct," and he insisted that "future American lawyers must develop these qualities beginning in law school." Burger, The Special Skills of Advocacy, 4 ALI-ABA CLE-REv. 4 (Dec. 14, 1973) (emphasis added).

192. See W. Gellhorn, Individual Freedom AND Governmental RestrainT 126 (1956); cf. Solicitors Act of 1957, 5 \& 6 Eliz. 2, c. 27, §§ 1 et seq.

193. The United States Supreme Court has asserted that those aliens specially permitted to practice were distinguished lawyers and a credit to the profession. Bradwell v. State, 83 U.S. (16 Wall.) 130, 139 (1873). See also In re O'Sullivan, 267 F. 23 (D. Mout. 1920); Howden v. State Bar, 208 Cal. 604, 283 P. 820 (Cal. 1929); In re Emmet, 2 Cai R. 386 (N.Y. 1805).

An old provision of the Indiana Constitution, which gave the privilege to all persons of good moral character, is quoted in In re Leach, 134 Ind. 665, 34 N.E. 641 (1893). Some states do not require citizenship today.

194. A resident alien eurolled in an American law school, if Chief Justice Burger's 
ish system can be called elitist in comparison to the American, where the organization of the courts and the bar have traditionally remained closer to the people, ${ }^{195}$ it would seem more likely that access to the profession would be granted to aliens in pluralistic and heterogenous America where the legal profession is perceived publicly as an open profession to which all who can develop the necessary competence can aspire. ${ }^{108}$ Not so, however, if Chief Justice Burger had his way. $\mathrm{He}$ would not grant British (or Canadian) immigrants a constitutional right to practice law in the Umited States although he would welcome their high standards of ethics and conduct. ${ }^{197}$

\section{B. Future Practice of Law by Aliens in the United States}

Griffiths has a two-pronged positive impact on the practice of law by aliens in the United States. First, states can no longer exclude a resident alien from state bar membership on the basis that the applicant lacks United States citizenship and has no intention of becoming a citizen in the future. Secondly, Griffiths may have the effect of biberalizing restrictive rules against the "practice of law" by nonresident aliens in the United States, at least initially in the area of foreign and international law.

Griffiths fails, however, to provide the resident alien lawyer with access to federal legal positions which require citizenship, or to elective or non-elective "official offices" of a state's "pohtical community" (e.g., judgeships, which can only be filled by citizens in cominumities which make citizenship a prerequisite). The decision further fails to extend expressly to nonresident alien lawyers the right to give "legal advice" in the Umited States, even if they are otherwise qualified.

Of course, bar adinission agencies also can still impose general admission requirements not related to citizenship. Traditionally these have related to capacity and fitness to practice law-specifically to proof of intellectual attainment, moral character, and durational state

arguments for citizenship requirement prevailed, could not even learn some of the officerof-the-court qualities which he urged should be learned in law school. As a noncitizen he would be precluded from participating in clinical education programs, such as a Law Student in Court program, designed to teach the qualities Chief Justice Burger has in mind. See Note, Admission to the Bar, supra note 130, at 689 .

195. See MacCrate, Populist and Elitist Conceptions of the Bar, 5 ALI-ABA CLE REv. 4 (March 8, 1974).

196. Id.

197. See also In re O'Neill, 90 N.Y. 584 (1882). Today the bars of Britain and Canada (e.g., Ontario Province) maintain these admirable standards of ethics and conduct even though they have abolished "good moral character" investigations. See note 214 infra. 
residency. In light of Griffiths, some states may also develop additional general requirements related to "citizenship" qualities, such as the applicant's ability to support, familiarity with, and devotion to the principles of the Constitution, if reasonable standards for measuring these qualities can be developed.

The first condition an alien applicant to the state bar must meet is Griffiths' threshold requirement of resident alien status. If the present circumstances are a guide for the future, inost alien bar applicants will be students who are about to finish, or have just finished, a threeyear law school curriculum. The applicant is usually not a foreign practitioner who also lolds an American law degree and desires to obtain full-time employment in the United States after practicing abroad. ${ }^{108}$ Many aliens currently enrolled in American law schools entered the United States on student or exchange student visas rather than resident alien (immigration) visas. ${ }^{199}$ Most entered an American undergraduate college or a non-law graduate school before entering law school, and only a small proportion entered the J.D. prograin after studying or practicing law abroad. ${ }^{200}$

Since the threshold requirement for state bar admission is resident alien status, those students with exchange student or student visas would not be able to gain admission. However, applicants with student visas may be able to change their visa status to resident alien without leaving the country if they are married or otherwise related to an American citizen or resident alien. ${ }^{201}$ Exchange students may do so under the same conditions if their stay in the United States was not financially sponsored by their home nation's government. ${ }^{202}$ Nonresident student

198. Questionnaire information received by the author from all state bar admission agencies in 1971 and 1972 revealed that only a negligible number of resident aliens who had been admitted or whose applications were pending were foreign practitioners. Of course, in areas like New York and Miami there are a number of naturalized citizen applicants who have practiced law in their former countries.

199. Based on telephone interviews with admission officers at ten midwestern and eastern law schools.

200. See note 199 supra.

201. The Immigration and Nationahty Act, 8 U.S.C. $\$ 1182(a)(14)$ (1970), provides that all immigrants "other than the parents, spouses, or children of United States citizens or of aliens lawfully admitted to the United States for permanent residence" who seek to enter the United States for the purpose of performing skilled or unskilled labor shall be excluded unless the Secretary of Labor certifies that "there are not sufficient workers in the United States who are able, willing, qualified, and available . . . to perform such skilled or unskilled labor," and that "the employment of such aliens will not adversely affect the wages and working conditions of the workers in the United States similarly employed." (Emphasis added.) See also id. \$ 1153(a).

202. The 1970 Congress passed legislation which amended the foreign residency requirement of section 212(e) of the Immigration and Nationality Act. Id. § 1182(e), 
aliens who are not directly related to an American citizen may, shortly before graduation from law school, obtain a job offer and thereafter apply for an immigration visa immediately as a "professional,"203 preferably with a supporting statement from the applicant's future employer that he considers the applicant's skills of a special nature, that his or her employment will not adversely affect the employer's hiring of otherwise similarly skilled American applicants, ${ }^{204}$ and that the employer will "sponsor" the applicant. (The latter statement of future employment would be helpful for anyone who wants to change his status from a student-type visa to an immigration visa.) If the applicant is not permitted to change his visa status while in the United States, he should attempt to show that returning to his lome country would work a hardship upon an American citizen (e.g., a relative here). If he must return to his lome country he may contimue, or begin, to process his visa application there.

After the applicant has met the threshold visa requirement, one of the major requirements he has to meet is that of "imtellectual attainment." This usually means an undergraduate degree or its equivalent, graduation from an accredited law school, and ultimately passage of the state bar examination. ${ }^{205}$ Because most resident alien applicants will have graduated recently from an accredited Ameriean law school, they should meet this requirement as easily as citizen applicants. Some resident alien applicants who do not possess a three-year J.D. degree from an accredited American law school but have a foreign law degree and have practiced abroad for a period of time may also gain admission in some states because of special regulations. ${ }^{208}$

formerly ch. 477, § 212(e), 66 Stat. 188 (1952), as amended by Mutual Educational and Cultural Exchange Act of 1961, Pub. L. No. 87-256, § 109(c), 75 Stat. 535. This provision had required that the exchange student return to his home country for two years before becoming eligible to apply for an immigration visa.

203. Section 101(a)(32) of the Iminigration and Nationality Act defines the term "profession" and includes the profession of lawyer. 8 U.S.C. \& 1101(a)(32) (1972). Section 203(a)(3) of the Act provides that visas shall be made available to qualified immigrants who are members of the professions or who because of their exceptional ability in the sciences or arts will prospectively substantially benefit the national economy, cultural interest, or welfare of the United States. Id. \$1153(a)(3). See note 201 supra.

204. See note 201 supra.

205. National CONFerence of Bar Examiners, The Bar Examiner's Handbook 15-20 (1968).

206. See, e.g., Rules For AdMISSION to the Bar of Indiana AND tHe Discipline OF ATTORNEYS, rule 6: "ADMISSION ON FOREIGN LICENSE: Any person who has been admitted to practice law in the highest court . . . in another country whose jurisprudence is based upon the principles of English common law, may be admitted to practice law" provided, inter alia, that the applicant has practiced law five years of the seven immediately preceding. 
Another traditional requirement which the resident alien bar admission applicant must usually meet is that of "good moral character." Historically, this term has been difficult to apply both in the context of citizenship requirements, which have demanded "good moral character" of applicants since $1790,{ }^{207}$ and bar admission requirements, which have been as austere or benign as the states desired. ${ }^{208}$ The "good moral character" requirement, in the citizenship context, has been interpreted to mean moral character at the level of the average citizen of the community in which the party hives. ${ }^{209}$ However, in the bar admission context the requirement has been increasingly limited to such code phrases as "officer of the court," "loyalty," "appreciation of American political imstitutions and local custonus," and the like, with the basic thrust a requirement of moral character "better" than that of the average citizen. ${ }^{210}$

Recently this trend towards a demanding interpretation of "good moral character" for bar admission purposes has been interpreted by the United States Supreme Court. In three decisions the Court has weakened the discriminatory usage of the nebulous term "good nroral character" and has narrowed the scope of questions that may be legitimately asked of prospective members of a state bar regarding moral character, participation in certain esoteric organizations, and belief in a constitutional form of government. ${ }^{211}$

Some states allow law schools to certify a graduate's "good moral character" based on the faculty's observation of the student over a three-year period and on evidence brought to the school's attention during this period. ${ }^{212}$ The standard employed in most states in recent years has moved closer to one of "dishonorable conduct relevant to the occupation," 213 with a presumption that the applicant is loyal to the constitutional form of government while at the same time respecting the

207. See Act of March 26, 1790, ch. 3, § 1,1 Stat. 103 (repealed 1795). The Immigration and Nationality Act currently provides that "[n]o person shall be naturalized unless [he] . . (3) ... has been and still is a person of good moral character . . .." 8 U.S.C. $\& 1427$ (a) (1970) (emphasis added). Although the Act presently attempls to define the term, id. $\S 1101(\mathfrak{f})$, its difficulty in application remains. See generally In re Edgar, 253 F. Supp. 951 (E.D. Mich. 1966).

208. See 106 U. PA. L. Rev. 753, 755 (1958).

209. See In re Hopp, 179 F. 561,563 (E.D. Wis. 1910).

210. See National CONFERENCE of BAR EXaminers, supra note 205, at 48-107.

211. Law Students Civil Rights Research Council, Inc. v. Wadmond, 401 U.S. 154 (1971); In re Stolar, 401 U.S. 23 (1971); Baird v. State Bar of Ariz., 401 U.S. 1 (1971).

212. Kanner, Dual Character Investigation: At Time of Law School Registration and Prior to the Bar, 30 BAR EXAMINER 60 (1961).

213. See generally Selinger \& Schoen, "To Purify the Bar:" A Constitutional Approach to Non-Professional Misconduct, 5 NATURAL ResourCes J. 299 (1965). 
applicant's first amendment riglits, ${ }^{214}$ including so-called "un-American" political beliefs.

Because citizenship status is no longer a legitimate per se prerequisite to the practice of law after Griffiths, there is a possibility that concerned state bar admission officers may fashion the "good moral character" requirement into a broader "citizenship" requirement, with a stress on American character. They could place the concept into operation in a bar admission test by using some of Justice Rehnquist's "integration" and Chief Justice Burger's "officer of the court" criteria as measurements of "citizenship." 215 The test requirement, in order to be constitutionally valid, would have to be a general one, applying to every applicant, resident alien and citizen alike. ${ }^{216}$ Such possible developinents could be closely linked to aspects of yet another requirement which the applicant may have to ineet: durational residency, soinetimes called the "local customs" requirement. ${ }^{217}$

Although most states still require an applicant to be a resident of the state at the time of application, federal courts have almost reached unanimity in finding that state residency requirements, which had once been labeled as "universally accepted," violate the equal protection clause $^{218}$ because there is "no rational relationship between "fitness or capacity to practice law' and the knowledge of 'local custoin." "210 A short durational residency may be constitutional, but at least one court

214. See Brown \& Fasset, Loyalty Tests for Admission to the Bar, 20 U. CHI. L. REv. 480 (1953). Not all jurisdictions inquire into activities of bar applicants. Id. at 483. In England, an applicant must have certificates of good moral character from two residents who have known him for one year. Comment, Bar Admissions-The Character Investigation as an Unconstituonal Scheme to Promote Conformity: Comment on LSCRRC v. Wadmond, 23 VAND. L. Rev. 131, 145-46 (1969). Canada (Ontario) has abohished investigations after finding no relationship between prior conduct and conduct subsequent to admission. Roberts, The Canadian Approach to Legal Education and Admission to the Bar, 36 BAR EXAMINER 6, 34 (1967).

215. See text accompanying notes 174-97 supra.

216. In re Griffiths, 413 U.S. at 725-27: of. Faruki v. Rogers, 349 F. Supp. 723 (D.D.C. 1972) (discussing a similar test of similar qualities (knowledge of American culture, history, and opinions) for applicauts to the American "foreign service").

217. All states but Florida, Illinois, Louisiana, and Ohio have them, though some have now been held unconstitutional. Note, Residence Requirements for Initial Admission to the Bar: A Compromise Proposal for Change, 56 CoRnell L. Rev. 831, 831 n.4 (1971).

218. Potts v. Honorable Justices of the Supreme Court, 332 F. Supp. 1392 (D. Hawaii 1971); Lipman v. Van Zant, 329 F. Supp. 391 (N.D. Miss. 1971); Webster v. Wofford, 321 F. Supp. 1259 (N.D. Ga. 1970); Keenan v. Board of Bar Examiners, 317 F. Supp. 1350 (E.D.N.C. 1970). See also Note, supra note 217, at 840-41. But see Suffering v. Bondurant, 339 F. Supp. 257 (D.N.M. 1972).

219. Keenan v. Board of Bar Examiners, 317 F. Supp. 1350, 1359 (E.D.N.C. 1970). 
has invalidated a six-month requirement. ${ }^{220}$ Whatever length a valid durational residency requirement may be, the state cannot treat the resident alien differently from the citizen applicant after Griffiths. ${ }^{221}$

Griffiths' second major impact is that it may also provide the impetus to resolve the question of the extent to which, and the conditions under which, a non-immigrant lawyer, properly qualified to practice law abroad and perhaps also with American legal training, should be permitted to "give legal advice," or to "practice" and/or "establish" an office in the United States. ${ }^{222}$ At the inoment, a foreign lawyer, i.e., one who has not entered the United States on a resident-alien (immigration) visa, has no established right to give direct legal advice to American clients in the United States or to inaintain a law office here, even if he wants to practice foreign and international law exclusively. ${ }^{223}$ Although the United States Supreme Court under its rules may accord a foreign lawyer the right to appear pro hac vice when associated with an American lawyer ${ }^{224}$ and this practice is followed in the state supreme courts, it can be argued persuasively that the ad hoc nature of a pro hac vice appearance does not meet the broad needs of clients or of lawyers in international and foreign law practice.

The problems are analogous to problems experienced by American lawyers engaged in interstate practice in the United States. These problems have been given recognition by nany nembers of the judiciary in recent cases which may mark the beginning of an expansion of the right to practice in interstate matters. ${ }^{25}$ This beginning, together with the reasoning employed in Griffiths, could also signal the extension of the right to practice, at least in a limited fashion, to for-

220. Potts v. Honorable Justices of the Supreme Court, 332 F. Supp. 1392, 1398 (D. Hawaii 1971). Compare the six month residency requirement in the filing jurisdiction for resident aliens filimg for naturalization. Immigration and Nationality Act, 8 U.S.C. $\S 1427$ (a)(1) (1970).

221. Compare the Foreign Service's illegal demand that an applicant prove that he has been "a citizen of the United States . . . for at least ten years," 22 U.S.C. $\$ 910$ (1970), which was ruled unconstitutional in Faruki v. Rogers, 349 F. Supp. 723 (D.D.C. 1972), discussed in Note, Naturalized Citizens-Equal Protection, 6 INT'L L. \& PoL. J. 311 (1973).

222. Griffiths' impact on the American's right to "practice" and "establish" abroad is discussed in text accompanying notes 237-58 infra.

223. See, e.g., In re Roel, 3 App. Div. 2d 742, 160 N.Y.S.2d 982 (1957).

224. S. CT. OF U.S. REV. R. 6.

225. See, e.g., Martin v. Walton, 368 U.S. 25 (1961); Sanders v. Russell, 401 F.2d 241 (5th Cir. 1968); Spanos v. Skouras Theatres Corp., 364 F.2d 161 (2d Cir.), cert. denied, 385 U.S. 987 (1966); Appel v. Remer, 43 N.J. 313, 204 A.2d 146 (1964). The problems and privileges of interstate practitioners are discussed in Note, Attorneys: Interstate and Federal Practice, 80 HARv. L. Rev. 1711 (1967); Note, The Practice of Law by Out-of-State Attorneys, 20 VAND. L. REv. 1276 (1967). 
eign practitioners who would like to serve foreign or American chents in foreign and international law matters here in the United States without having to associate with a local practitioner. Services rendered by a single coinpetent attorney may produce greater efficiency, increased substantive accuracy of the advice, and lower costs of services for the American client. There is a demand for wider legal services of this sort for which the contributing factors are ease of travel and communication, the redistribution of wealth, and the rapid and expanding developnent of multinational, transnational, and interstate business transactions. Griffiths, having removed the strong countervailing force of the citizenship requirenent, may persuade legislatures, bar associations, and courts to neet the demand of these factors by developing licensing rules for foreign attorneys to practice at least in a limited fashion as long as they meet the competency, legal ethics, and professional conduct requirements of the local bars. ${ }^{226}$ States may be aided in their efforts by closely nronitoring similar developments in other parts of the world, such as in the European Economic Commumity, the plans of which are discussed below, ${ }^{22 \tau}$ and they may even want to enter into bilateral or multilateral agreements regarding waiver of local qualificational requirements in exchange for another country's citizenship and qualificational waiver.

Meanwhile, foreign attorneys who practice abroad but who also desire to practice in such cities as New York, Washington, Chicago, or

226. See proposals in 43 Report of tHE N.Y. STATE BAR Ass'N 293-94 (1920) and in THE ASS'N OF THE BAR OF THE CITY OF N.Y., YEAR BooK 256 (1957). This topic has also been discussed at a meeting called jointly by the International Bar Association and the Union Internationale des Advocats, April 15-16, 1972, in Estorial, Portugal. See INT'L B.J. 102 (May 1972).

A group of international law firms based in New York, organized as the Ad Hoc Committee on Foreign Lawyer Regulation, has advanced a proposal in New York Statc calling for a liceused, supervised profession of "legal consultants" to which experienced foreign attorneys could be admitted without undergoing full American legal training or passing a state bar exammation. These legal consultants would be authorized to offer legal advice in appropriate fields, such as international, comparative, and foreign law, but would be excluded from activities requiring considerable familiarity with American law-and procedure. Sce Interim Rep. by the Ad Hoc Comm. on Foreign Lawyer Regulation to the Presidents of the N.Y. Bar Ass'n, the N.Y. County Lawyers Ass'n, and the Ass'n of the Bar of the City of N.Y., July 27, 1972. Currently there is an Ad Hoc Committee proposal before the New York Court of Appeals calling for the adoption of a new part 530 of the Rules of the Court of Appeals which provides for a "license without examination" for "legal consultants." The Ad Hoc Committee's proposal has failed in the legislature, but the Committee plans to renew its efforts in future legislative sessions. Of course, if efforts on the state level fail, proponents could try to persuade Congress to establish, by statute or treaty, a federally licensed profession of foreign legal advisors authorized to practice foreign, comparative, and international law, and to appear as counsel before federal courts and administrative agencies.

227. See text accompanying notes 247-53 infra. 
Los Angeles ${ }^{28}$ will have to meet all of the general bar admission requirements discussed above. However, Griffiths will aid large American-based international law offices and American-based imternational corporations. They will now have increased opportunity to transfer foreign legal experts to their American home offices where they can become familiar with American operations and clients in an apprenticeship fashion. Simultaneously, the expert can attend a local American law school either full-time for two years, arranging for at least one year credit transfer from his own legal studies abroad, or attend law school on a part-time basis and ultimately become a member of the local bar. ${ }^{229}$ Since the foreign legal expert does not have to renounce his citizenship, such a program should become attractive for numerous young internationally-minded foreign legal experts. Once they are inembers of an American bar in addition to being adimitted to court practice in a foreign country, they will have moved one step further toward becoming truly international legal advisers and will be most useful to a United States corporation with many foreign operations or to a law office with internationally-minded clientele. ${ }^{230}$

228. These cities are most attractive to foreign practitioners because of the regions' high concentration of international-minded business headquarters and law firms.

229. In addition to these opportunities, California and New York still permit, as an aiternative to attendance at a law school, a four-year supervised apprenticeship in the office of a practicing attorney. CAL. S. CT. R. 9; N.Y. CT. APr. R. 520.5. A September, 1973, revision of the District of Columbia Rules includes a unique provision which permits a graduate of a non-accredited law school to satisfy the legal education requirement by obtaining twenty-four additional credits at an accredited school. D.C. CT. APP. R. 46.1(b)(4). This might be interpreted to allow foreign-trained students to sit for the bar examination after a year of LL.M. study in the United States. Another factor which may act as an incentive for foreign law graduates to join an American law firn and/or law school temporarily is the possibility that work aud study in the United States will be credited towards the lengthy apprenticeship periods required in their hoine countries. For example, European law graduates who pursue an LL.M. at an American law school inmediately after their graduation usually receive permission to apply this time period towards their local apprenticeship periods. Finally, beginning in 1972, most states adopted the standardized Multistate Bar Examination as a nuajor part of their bar adnission examinations. Covington, The Multistate Bar Examination, 1973 NaTional BAR EXAMINER 18. This development may reduce the difficulty of the examination of the foreign applicant by emphasizing general principles and legal philosophy rather than peculiarities of local jurisdictions.

230. American corporations with extensive foreign operations are already used to hiring German, Freuch, British, Latin-American, and other nationals as junior executives. The corporations bring these employees to the United States on immigration visas for lengthy training and work experience and then put thein into leading positions in their hoine countries. Because they have resident alien visas, these employees can be readily transferred from their assignments abroad to the United States. The only visa-related difficulty is that these employees must return to the United States periodically in order to retain their immigrant status. So far, this has been no obstacle, and such a program could be apphed to legal practitioners. 
Griffiths, despite its positive impact on the practice of law by aliens in the United States, will not liberalize all aspects of the practice of law. The decision's first limitation is that the Court expressly upheld the states' right to exclude noncitizens from official elective and nonelective positions which are part of the states' "political community."231 A second limitation of the Graham-Sugarman-Griffiths series is the Court's exclusive doctrinal employment of the fourteenth amendnient and its refusal to use the federal supremacy or preemption and fifth amendment arguments. ${ }^{232}$ Consequently, resident aliens, though eligible for state bar neembership, will not be able to obtaim federal legal employment as long as citizenship remains a prerequisite for adımission into the federal civil service. ${ }^{233}$ However, the Court may rule in favor of the resident alien on this issue in the future on constitutional grounds or by interpretation of congressional policies. ${ }^{234}$ A third limitation in the private sector, not directly related to the particular cases discussed here, nuay render the cases' positive impact partially impo-

231. See note 173 supra and accompanying text. Of course, the Court's discussion of "pohtical community exclusion" is by way of dicta, and arguments can be made that aliens should not be so excluded. See, e.g., The Supreme Court of California 1971-72, Constitutional Law, 61 CaLIF. L. Rev. 345, 365 (1973); Recent Decisions-Constitutional Law-Rights of Aliens-Citizenship as a Requirement for Admission to the Bar is a Violation of Equal Protection, 4 GA. J. OF INT'L \& CoMP. L. 206, 214-15 (1974). However, the views expressed at some length in Sugarman presumably reflect those of the eight justices who joined in the opinion, and Justice Rehnquist's dissenting opinion clearly indicates that he would uphold such state exclusionary action.

232. E.g., In re Griffiths, 413 U.S. at 718 n.3.

233. See notes 90 supra and 234 infra.

234. See generally Comment, Aliens and the Civil Service: A Closed Door?, 61 GEO. L.J. 207 (1972). In a decision filed shortly after Graham, a federal district court upheld the exclusion of aliens from the federal competitive civil service. Mow Sun Wong v. Hampton, 333 F. Supp. 527 (N.D. Cal. 1971). However, the case was reversed and remanded by the Ninth Circuit Court of Appeals and certiorari has been granted by the United States Supreme Court. Hampton v. Mow Sun Wong, 500 F.2d 1031 (9th Cir. 1974), cert. granted, 42 U.S.L.W. 3678 (U.S. June 10, 1974) (No. 73-1596). The question for appeal is whether United States Civil Service Commission regulations excluding resident aliens from employment in federal competitive civil service violate the due process clause of the fifth amendment of the constitution. See also Das, Discrintination in Employment Against Aliens-The Impact of the Constitution and Federal Civil Rights Laws, 35 U. PrTT. L. REv. 499, 528-42 (1974).

In another very recent case, a three-judge District Court for the District of Puerto Rico followed the Ninth Circuit's holding in Mow Sun Wong and held that the Civil Service Commission regulation and statute which excluded aliens from federal civil service employment were unconstitutional. Ramos v. United States Civil Serv. Comm'n, 376 F. Supp. 361 (D.P.R. 1974). This action had been consolidated with another action attacking a federal statute denying disaster loans to alien farmers; this exclusion of aliens was likewise declared unconstitutional. Id. at 368. Principally on the strength of the arguinents in Sugarman, Graham, and Griffiths, the court held that the federal government may not practice discrimination against resident aliens forbidden to the states. 
tent. This limitation is the unresolved question of whether Title VII of the Civil Rights Act of 1964 can be construed to apply to individual einployers who discriminate against particular applicants because they are not citizens, ${ }^{235}$ and the further uncertainty as to the applicability of the broad language and indefinite remedy of the Civil Rights Act of 1866 to discrimination against aliens by private employers. ${ }^{236} \mathrm{Un}$ less the noncitizen legal practitioner can deinand and enforce equal treatment in the private labor nnarket, Griffiths' liberalizing effect on bar admission rules may not completely equalize private employment opportunities for noncitizen lawyers; im particular, those with readily identifiable racial or national origin characteristics. ${ }^{237}$

\section{Future Practice of Law by Americans Abroad}

At the present time, cooperation with foreign colleagues has become almost routime in an increasing number of American law offices. Even partnerships between members of foreign and American bars exist, and inany large law firms have opened branch offices in Brussels, Paris, London, and elsewhere in the world.

However, the mere existence of such partnerships does not imply that the partners are also admitted to practice in several countries, and "law practice" in foreign branch offices is usually carried out by foreign attorneys, Americans being limited to activities of the office-supervisory, pro hac vice, or "legal advice" nature because of local restrictions on the practice of law by noncitizen and/or foreign-educated practitioners. One of the major consequences of Griffiths' striking of the citizenship requirenent for admission to the bar may be that it can lead to greater liberalization of bar admission rules abroad and expansion of foreign and international law practice by Americans abroad.

The problems facing Americans who want to practice law abroad become most apparent from a description of the practice situation in a particular country, for exaunple, France, and in a block of nations

235. 42 U.S.C. $\$ \S 2000 \mathrm{e}$ et seq. (1970); see Comment, Discrimination Against Aliens, 51 TeX. L. Rev. 128, 133 (1973). In Espinoza v. Farah Mfg. Co., 414 U.S. 86 (1973), the Supreme Court held that Title VII does not prohibit an employer from refusing to hire aliens per se, but added that Title VII "prohibits discrimination on the basis of citizenship whenever it has the purpose or effect of discriminating on the basis of national origin." Id. at 92; see Das, supra note 234, at 542-43.

236. In Guerra v. Manchester Terminal Corp., 350 F. Supp. 529 (S.D. Tex. 1972), a federal district court held that the Civil Rights Act of 1866, 42 U.S.C. $\$ 1981$ (1970), prohibits private employment discrimination on the basis of alienage. See Das, supra note 234 , at 546-53.

237. See Comment, Alien Employment Rights: Espinoza v. Farah Manufacturing Co., 6 INT'L L. \& Por. J. 297, 305 (1973). 
for example, the European Economic Community (EEC). In 1972 there were at least twenty-six law offices in Paris the staffs of which were largely coinposed of American-educated attorneys. ${ }^{238} \mathrm{~A}$ nuniber of these offices are divisions of American law firms in New York, Chicago, and Los Angeles. The clientele of nost of these firms consists inainly of nultinational business entities which need advice on the laws of several countries to conduct their coniplex transactions, particularly regarding tax, antitrust, and licensing laws. ${ }^{238}$ France, like soine other countries, has traditionally defined the term "practicing law" less hoinogenously and all-inclusively than the United States. France historically has recognized several types of activities which conprise the practice of law, among them giving "legal advice" (conseil juridique). ${ }^{240}$ Whereas French citizenship was a prerequisite for such professional roles as advocat, avoué, and notaire, noncitizens traditionally were permitted to operate as "legal advisors," that is, to concentrate on chent counseling without the right to niake local court appearances. Not being able to establish a full-fledged law practice poses only slight problems for American attorneys whose clients primarily seek counseling service regarding European tax, antitrust, and hicensing law problems.

As American attorneys abroad liave increasingly and successfully been seeking to counsel international clients who usually have headquarters in the United States, hostility toward American attorneys has become evident in various countries. ${ }^{241}$ Again, the situation in France

238. See 4 Martindale-Hubbell Law Dir. 3138B-3164B (104th ed. 1972).

239. Note, Foreign Branches of Law Firms: The Development of Lawyers Equipped to Handle International Practice, 80 Harv. L. REv. 1284, 1285-86 (1967).

240. See LePaulle, Law Practice in France, 50 Colum. L. Rev. 945, 947 (1950); Comment, The Reform of the French Legal Profession: A Comment on the Changed Status of Foreign Lawyers, 11 ColuM. J. TRANSNaT'L L. 435 (1972).

241. For an indication of this hostility, see the oral deliberations by the membership of the International Bar Association in July, 1966, wherein the hypothetical establishment in Brussels of branch offices of American-based law firms was discussed. Eleventh Conference of the. Int'l Bar Ass'n, 11 INT'L B. Ass'N Conference Report 91-94 (1966).

The Consultative Commission of the bar associations of the European Community adopted a resolution in April, 1972, which conveyed the existence of considerable suspicion and frustration of the licensed European attorney towards the mobile and wealthy American international business lawyer. The resolution attacked the unregulated admission of foreign lawyers to practice as legal advisors in member states, insisting that their entry be conditioned on proof of the existence of full reciprocity for European lawyers in their country of origin and approval of the bar association of the host country. It further called on the member bar assuciations to insist that local attorneys in the member states abide by the Commission's prohibition against dealing with lawyers from third countries established in member states whose bar associations have not approved their activity. See Proceedings of the Comm'n Consultative des Barreaux des Pays des Communautes Europeennes, Edinburgh, Scotland, (Apr. 29, 1972). However, the Consulta- 
is illustrative. Traditionally, American attorneys in Paris were allowed to compete with French lawyers in France, whereas French lawyers were faced with severe restrictions in the United States. ${ }^{242}$ This unequal situation was somewhat relieved by a reciprocal United States/ France agreement in 1960 which allowed nationals and companies froin each others' country to engage "lawyers and personnel who by reason of their special capacities are essential to the functioning of the enterprise" as long as they "fulfill the conditions necessary to the exercise of their calling under the applicable legislation."243 This facilitated retainer of French attorneys in the United States to advise French nationals and companies on matters of foreign law, but did not grant them the right to open an American branch law office because of the American states' bar membership requirements, which apply not only to "law practice" but also to such limited activities as giving "legal advice" on specialized inatters.

French officials continued to express concern about the lack of reciprocity in the right to establish a law office, even for the limited purpose of legal counseling on specialized matters. ${ }^{244}$ In the hope of bringing indirect pressure to bear on legislatures of American states, the French recently passed legislation which makes an American law firm's future practice of French law in France dependent upon America or individual states granting reciprocity to French nationals within five years. $^{245}$ Otherwise, practice by foreigners is to be limited to foreign law (any except French) and international law and subjected to various new regulations. ${ }^{248}$ This means that even if American states deny reciprocity, Americans in France will be able to continue to counsel on foreign and international law, a rule which is still considerably more liberal than the present American regulations which apply to the visiting French attorney who is not a graduate of an American law school and not a inember of an American bar.

Recent developments in the EEC also highlight some issues bear-

tive Commission has no direct political influence with the governments of the countries belonging to the Community.

242. See Matter of N.Y. County Lawyer's Ass'n, 3 N.Y.2d 224, 144 N.E.2d 24, 165 N.Y.S.2d 31 (1957), appeal dismissed, 355 U.S. 605 (1958). This case, also known as the Roel case, held that a Mexican attorney who had opened an office in New York to advise clients of ways to get a Mexican divorce was illegally engaged in the practice of law within the state.

243. Convention of Establishment with France, Aug. 29, 1960, [1960] 2 U.S.T. 2398, 2412.

244. Gazette du Palais, Dec. 22-23, 1971, at 28.

245. Statute of Dec. 31, 1971, [1972] J.O. 131 (Fr.).

246. Gazette du Palais, Oct. 31-Nov. 2, 1971, at 24. 
ing on the American attorneys' ability to practice abroad. The Rome Treaty, which established the EEC, mandates in article 52 that "freedom of establishment and services" should be guaranteed, ${ }^{247}$ except that pursuant to article 55 those activities which involve the exercise of "official authority" are to be excluded from article 52's mandate. ${ }^{248}$ Although some free novement of labor has been achieved in the EEC today, none of the national restrictions on the professions has been liberalized. Like the dissenters in Griffiths, the governments of Germany ${ }^{249}$ and Luxembourg ${ }^{250}$ have taken the position that lawyers exercise "official authority," and therefore membership in this profession should be restricted to nationals. However, other EEC countries liave disagreed. An EEC Council Directive in $1969^{251}$ earmarked for liberalization at least a few "service" activities of lawyers, ignormg for the time being the tougher question of "establishment."252 The Directive proposed to grant visiting foreign practitioners the following rights: consultation, oral conduct of defense, access to court files, visit to a person in detention, and presence at preliminary inquiries by authorities.

The EEC Directive represents the modest beginning of a process which should eventually abohish citizenship and national academic degree requirements. However, it has not yet been resolved whether this will be achieved within the EEC or by special bilateral and multilateral treaties between member states. ${ }^{253}$

The examples of France and the EEC sliow that most countries protect their legal profession agamst intrusion by foreigners. But they also indicate that the level of parochial protectiomsm abroad may still give the American attorney more opportunity to provide services

247. Treaty Establishing the European Economic Community, done March 25, 1957, 298 U.N.T.S. 11, 37. Article 52 provides that "[f]reedom of establishment shall include the right to engage in and carry on non-wage-earning activities . . . nnder the conditions laid down by the law of the country of establislıment for its own nationals . . . ."

248. Id. at 39. Article 55 provides that the principles of the cliapter on "the right of establishment" shall not apply to occupations which involve, even occasionally, the exercise of official authority.

249. Under German law the lawyer is termed an "officer of the court" and this applies at all times. Art. 1 BRAO. But the definition in Germany, like that in the United States, is only a reflection of the public duty of lawyers. RosenberG-SchWAB, ZiviLPROZESSRECHT 119 (1969). See generally Schneider, Towards a European Lawyer, 8 COMMON MARKET L. Rev. 44 (1971).

250. See Maestripieri, Freedom of Establishment and Freedom to Supply Services, 10 Common MARKET L. REv. 150, 172 (1973).

251. EEC Council Directive of April 17, [1969] J.O. C 78/1. This proposal was adopted by the EEC Economic and Social Committee on Feb. 2, 1970.

252. For a general discussion, see Lando, The Liberal Professions in the EEC, 8 COMMON MARKET L. Rev. 343 (1971).

253. Id. 
abroad than most American states grant to foreign practitioners. Furthermore, these two examples offer insights into the special problems involved in liberalizing bar admission rules on an international scale.

American states which want to tackle this problem by reciprocal agreements, as Chief Justice Burger has suggested, should be in an improved bargaining position not in spite of Griffiths, as Chief Justice Burger implies, but because of the majority's holding in Griffiths. Some countries (e.g., Great Britain) do not require citizenship for the practice of law, ${ }^{254}$ and Griffiths, by removing the citizenship requirement, has opened the way to removal of the remaining obstacles to the free flow of practitioners between these other countries and the United States.

Most nations, lowever, exclude Americans even if the applicant meets all other local qualificational requirements. ${ }^{255}$ Practitioners of these countries who want to have the right to practice domestic law in the United States, or to give legal advice in the United States on international and foreign law matters, would seem to be at an advantage because of Griffiths. However, a more careful analysis will show that in most cases this is not true. Most American states require an American law degree, passage of bar examination, minimal durational residency, and a showing of good moral character. These requirements, coupled with the fact that bar membership in one state does not automatically entitle one to practice in another, in most cases operate as de facto obstacles to a foreigner's desire to "practice" or "advise" in the United States. The educational and residency requirements make particularly good bargaining chips for reciprocal agreements regarding the full-fledged right to practice locally. For example, an American state might agree to waive some of these requirements and to require only passage of its own, or another state's, bar examination, some legal experience, and good professional standing in the applicant's home country. In exchange, the other country imight drop its citizenship prerequisite and impose similar reciprocal requirements on the American's right to practice abroad. ${ }^{256}$

254. See note 257 infra. Other examples are Norway, Norwegian Judiciary Act of August 13, 1915, No. 5, TT 218-25 (requires local law degree) and Japan, Japanese Private Lawyers Act, 1972 (requires Japanese Bar Examination and two-year Japanese Supreme Court apprenticeship). See note 255 infra.

255. E.g., Denmark, Danish Administration of Justice Act, $\$ 119$ (citizenship, Danish law degree, apprenticeship). Countries in which similar requirements exist imclude Brazil, Canada, France, Germany, Italy, Netherlands, and Switzerland. See note 256 infra.

256. For example, Sweden and France do not require a local law degree, although they do require citizenship. Argentina permits an alien with a foreign law degree to 
Most of these countries are probably even more interested in the lesser right to give "legal advice" than in the full-fledged right to "establish and practice" with its concomitant barrier of local bar examinations. American states could grant such limited rights and look for guidance to the rules proposed in the EEC and those which momentarily exist in France and other Western European countries. ${ }^{257}$ In ex-

practice if reciprocity exists through lateral conventions, Camara de Apel. Civil, Art. 75-79, Dec. 1967; similarly, Chile, Ley Organica del Colegio de Abogados, Sept. 1, 1941, art. 62.

257. Present day French and EEC regulations regarding the giving of "legal advice" are discussed in notes 238-53 supra and accompanying text.

The American lawyer in Belgium may give "legal advice" and act as a contractual agent, C. JuD. art. 428 (32 ed. Bruylant 1969), withont obtaining Belgian citizenship. But Belgiun has utilizcd immigration and employment regulations to control, with substantial restrictive impact, the activity of foreign "legal advisers." Foreign lawyers must obtain a work permit (carte professionale) from the Ministre des classes moyennes, Law of Feb. 19, 1965 (1965) MONITEUR BELGE 2007, must refrain from pleading before either courts or arbitral tribunals and from collecting claims; may provide legal services only to enterprises in which foreign capital predominates; and must prove foreign qualifications and membership in a recognized American law firm. Nusbaun, "In Belgium," in Busch, The Right of United States Lawyers to Practice Abroad, 3 INT'L LAWYER 617, 639 (1969). The citizenship requirement for the establishment of a fullfledged practice as avocat may be waived, C. JUD. art. 428 (32 ed. Bruylant 1969), but the applicant would have to fulfill difficult educational, capacity, and fitness requireinents, including a license en droit, a three-year clerkship, and an oath of allegiance. Blatch, The Structure of the Legal Profession in Belgium, 65 L. Soc. GAZ. 426 (1968).

In England the foreign lawyer who wants to establish a practice or associate with other foreign lawyers must obtain a permit from the Home Office. Aliens Order, art. 1(3)(b), [1920] 1 STaT. R. \& O. 138 (No. 448). This is usually issued if the applicant gives proof of his foreign qnalifications, snitability and fitness, and undertakes to abide by the regulations governing the conduct of the Enghish profession, cspecially those relating to advertising and obtaining busimess unfairly.

German statutes and practice offer American lawyers the opportunity to become licensed as legal consultants (Rechtsbeistaende). RBerG art. 1, sec. 1. The consultant is limited to consultation and advice within the district of the court by which he is admitted, and the American lawyer would be limited to giving advice on international law or the law of his state. I Verordnung zur Verhuetung von Missbraeuchen auf dem Gebiete der Rechtsberatung vom 13. Dez. 1935. Sec. II [1935] RGBI. I 1481, sec. 2. Application is made to the president of the district court (Landgericht) of the location where the foreign lawyer wants to establish himself. Id. Whether licensed in this way or not, American lawyers may conduct negotiations or consultation in Germany on behalf of either his foreign or German clients, provided such activity occurs in the ordinary course of his regular domestic practice. Brangsch, Beschraenkungen der anwaltlichen Berufsausuebung im Ausland, in LAUSANNe Conference Report, Eleventh ConFERENCE OF THE INTERNaTIONAL BAR Association-LAUSANNe, SwitzerLand, July 1115, 1966, at 40. The American may also appear and argue before the German courts alongside a German practitioner and appear alone in private arbitration proceedings. Id.

The American lawyer in the Netherlands may establish an office as a legal consultant and represent his chents before Dutch authorities and participate in arbitration proceedings. Van Heemstra, "In the Netherlands," in Busch, supra, at 619. Bar admission and full-fledged practice in courts requires citizenship, a local law degree and an oath of allegiance. Id. at 617-18. The practice rules in the Netherlands might be changed 
change for granting such limited rights to foreign practitioners, the various states should be able to obtain reciprocal rights for American attorneys and might also persuade the other country to drop the citizenship prerequisite for full local practice as well.

Griffiths has substantially advanced the possibility of such agreements because it will probably now be easier to persuade legislators, state supreme court judges, and bar admission officers to compromise on these requirements than it had been when the citizenship requirements were still valid. Griffiths sets the stage for agreements facilitating truly international law practice, and, on balance, American law firms, many of which already have branch offices abroad, should get the better part of such reciprocal bargains. ${ }^{258}$

\section{SUMMARY AND CONCLUSIONS}

Statutory employment restrictions against aliens have persisted in the United States for many decades, generally with judicial acquies-

in the near future to grant the foreign practitioner even broader rights in the areas of foreign and international law. (Information based on correspondence with Dutch Bar Association.)

The American lawyer in Switzerland may provide legal advice, draft legal documents, and represent his clients in contractual negotiations during temporary visits to Switzerland not exceeding eight days in any three-month period, and he can freely participate as an arbiter except in Swiss arbitration proceedings. Briner, in LAUSANNE CONFERENCE REPORT, supra at 74. Establishment of a full-fledged practice and attainment of bar membership would require citizenship. Id. For a display of Swiss animosity towards greater freedoin of participation by American lawyers, see 41 MITTEILUNGEN DES SCHWEIZERISCHEN ANWAITVERBANDES 20-24 (1973).

Helpful information about the practice of law abroad can be found in a report prepared by Peter Kisler for the Uniou Internationale des Advocats (UIA), following the UIA's twenty-third Congress in London in 1969. The summary of the results of the UIA survey can be found in DIE AUSUEBUNG Des RechtsanwaltsberUfes IM AUSLAND-RAPPORT GENERAL [presented at the twenty-fourth Congress in Paris (1971)].

258. Expectations regarding the possibility of entering into reciprocal agreennents should not be set too high because some obstacles, foreign and domestic, will be very difficult to overcome despite the removal of the citizenship barrier in the United States. For example, individual American states liave no control over federal barriers to the free inovement of lawyers across American borders, for instance, foreign visitors' work permit regulations. Also, existing multijurisdictional bar admission autonomy makes a state powerless regarding the rules of its neighbors. An example of a major problein abroad is the principle of "dual representation," that is, distinguishing between the functions of different kinds of lawyers-avoue, procurateur, barrister, solicitor, and so forth. Luxe1nbourg, Netherlands, Italy, Ireland, and England, to mention a few, would find it unthinkable that an American attorney would be allowed to settle in or visit their countries and perform the functions of both lawyer-types when the local professionals are not allowed to do so. In addition, some countries' courts are accessible to only a few local attorneys. For example, in the Gernan systein only a small number of German "Rechtsanwaelte" -about twenty, who are specially appointed-may conduct a case at the German Supreme Court. Art. 25, 171 BRAO. 
cence. Few of the discriminatory statutes have been challenged by litigation, probably because aliens were in suppressed economic positions and did not want to expose themselves to risk of monetary loss and further stigmatization. Alien law students have recently proved to be exceptionally litigious, however, and one of them recently obtained a most significant decision from the United States Supreme Court which ruled that aliens have the right to practice law in the Umited States if they otherwise qualify. An immediate consequence is that qualified resident aliens will be able to enter legal and, by implication, other professions. The Supreme Court's ruling, however, will have a broader impact in that it lays the foundation for a movement toward a truly internationalized practice of law in the United States, and perhaps abroad, for those individuals who want to overcome the renuaining built-in obstacles. 